SAND94-0301

Distribution

Unlimited Release

Category UC-721

March 1994

\title{
Assessment of an Active Dry Barrier FOR A LANDFILl Cover System
}

\author{
J.C. Stormont \\ Sandia National Laboratories \\ Albuquerque, NM \\ M.D. Ankeny, M.E. Burkhard, M.K. Tansey, and J.A. Kelsey \\ Daniel B. Stephens \& Associates \\ Albuquerque, NM \\ for \\ US Department of Energy \\ Office of Technology Development
}

\section{Abstract}

A dry barrier is a layer of geologic material that is dried by air flow. An active dry barrier system can be designed, instailed, and operated as part of a landfill cover system. An active system uses blowers and fans to move air through a high-permeability layer within the cover system. Depending principally on the air-flow rate, it is possible for a dry barrier to remove enough water to substantially reduce the likelihood of water percolating through the cover system. If a material with a relatively great storage capacity, such as processed tuff, is used as the coarse layer, then the efficiency of the dry barrier will be increased.

\section{MASTER}

DS YriBUTION OF THIS DOCUMENT 


\section{Contents}

1.0 INTRODUCTION $\ldots \ldots \ldots \ldots \ldots \ldots \ldots \ldots \ldots \ldots \ldots \ldots \ldots$

2.0 CURRENT LANDFILL COVER TECHNOLOGY $\ldots \ldots \ldots \ldots \ldots$

3.0 INCORPORATING A DRY BARRIER IN A COVER SYSTEM $\ldots \ldots \ldots \ldots 9$

3.1 WATER REMOVAL IN A DRY BARRIER COVER SYSTEM $\ldots \ldots .9$

3.2 ANALYSIS OF DRY BARRIER PERFORMANCE $\ldots \ldots \ldots \ldots \ldots 11$

4.0 ANALYSIS OF LANDFILL COVER SYSTEM APPLICATIONS $\ldots \ldots \ldots 17$

4.1 DESIGN CRITERIA FOR DRY BARRIER IN A COVER SYSTEM $\ldots \ldots 17$

4.3 DESIGN ANALYSIS OF A DRY BARRIER COVER . . . . . . . . . 19

4.4 A DRY BARRIER WITH COARSE LAYER STORAGE . . . . . . . . . . 24

5.0 APPLICATION DESIGN AND COST ANALYSIS $\ldots \ldots \ldots \ldots 27$

5.1 SYSTEM REQUIREMENTS $\ldots \ldots \ldots \ldots \ldots \ldots \ldots \ldots \ldots \ldots$

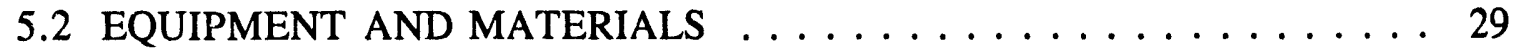

5.3 APPLICATION DESIGNS $\ldots \ldots \ldots \ldots \ldots \ldots \ldots \ldots \ldots$

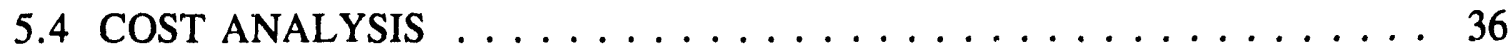

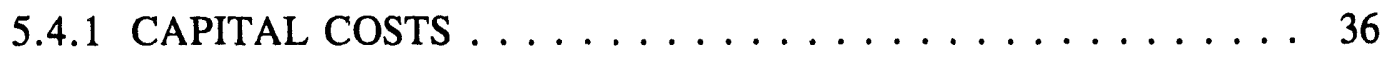

5.4 .2 OPERATING COSTS $\ldots \ldots \ldots \ldots \ldots \ldots \ldots$

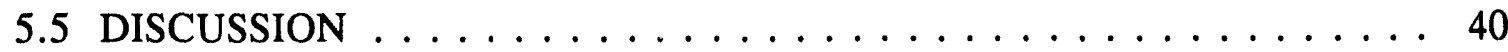

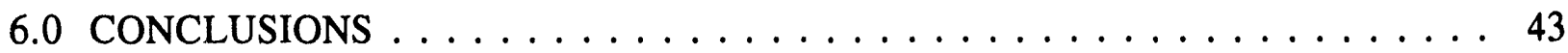

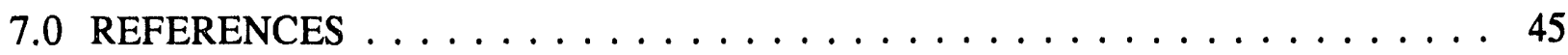

APPENDIX A: Assumed Material Properties $\ldots \ldots \ldots \ldots \ldots \ldots \ldots \ldots$ A-1

APPENDIX B: Blower Specifications and Costs $\ldots \ldots \ldots \ldots \ldots \ldots$ B-1

\section{FIGURES}

1. The EPA-recommended design for hazardous waste landfill covers $\ldots \ldots \ldots .4$

2. Basic capillary barrier design $\ldots \ldots \ldots \ldots \ldots \ldots \ldots \ldots \ldots \ldots \ldots \ldots$ 


\section{Contents (Continued)}

3. Drying power of Albuquerque air in terms of specific humidity . . . . . 10

4. Drying power of air equilibrated with $13^{\circ} \mathrm{C}$ soil in terms of specific humidity . . 11

5. Mechanisms of water movement induced by air flow in a fine-over-coarsecover system . . . . . . . . . . . . . . . . . . . 12

6. Model geometry and boundary conditions for numerical simulations of the upper three layers of a cover system $\ldots \ldots \ldots \ldots \ldots \ldots \ldots$

7. Initial saturations due to gravity drainage in the upper three layers of a cover system prior to establishing air flow through a coarse layer . . . . . . . 15

8. Simulated water removal as a function of time $\ldots \ldots \ldots 16$

9. Plan view of a dry barrier design unit showing piping configuration in the

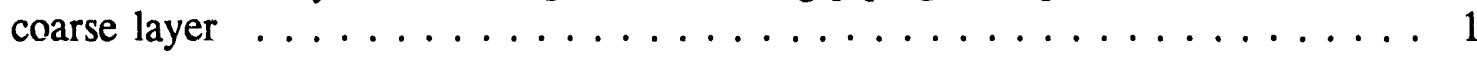

10. Water-removal rates for various permeabilities, flow rates, and pressure drops for a hectare-sized barrier with a well-length-to-well-spacing ratio of $2 \ldots 22$

11. Water-removal rates for a limited range of permeabilities and pressure drops for hectare-sized dry barrier with a well-length-to-well-spacing ratio of $2 \ldots \ldots 22$

12. Air-flow rates and differential pressures to achieve proposed design criteria

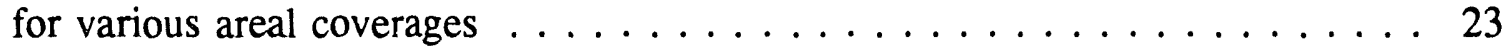

13. Estimated pressure losses as a function of areal coverage . . . . . . . . . 35

14. Capital and operating costs for the Albuquerque site . . . . . . . . . . 37

15. Capital and operating costs for the Los Alamos site . . . . . . . . . . . 38

16. Capital and operating costs for the Salt Lake City site . . . . . . . . . . . . . 39 


\section{Contents (Continued)}

\section{TABLES}

1. Observed Results for Hill AFB Study Over a Period of 45 Months . . . . . . . . . 8

2. Precipitation Data for Three Western US Sites $\ldots \ldots \ldots \ldots$

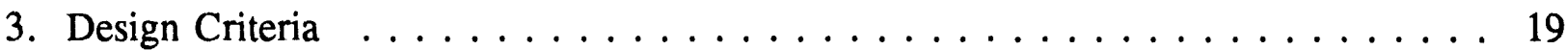

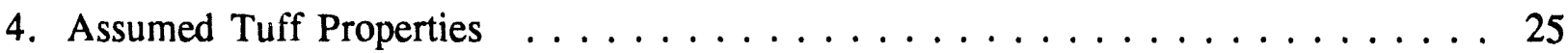

5. Dimensions of Design Unit Cells . . . . . . . . . . . . . . . . . 28

6. Flow Rates and Pressure Drops to Satisfy Design Criteria . . . . . . . . . . . . 29

7. Site-Specific Design for Albuquerque $\ldots \ldots \ldots \ldots \ldots \ldots$

8. Site-Specific Design for Los Alamos $\ldots \ldots \ldots \ldots \ldots \ldots$

9. Site-Specific Design for Salt Lake City . . . . . . . . . . . . . . . . . . 34

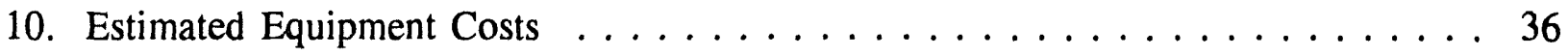




\subsection{INTRODUCTION}

Landfills, surface impoundments, waste piles, and some mine tailings are required to be covered on closure with an engineered cover or cap. The cover can vary from a simple soil cover to multiple layers of earthen materials and geosynthetics, depending on regulations, risks associated with the waste materials, and conventional practice in a particular industry. The principal purpose of covers is to limit the downward movement of precipitation through the waste and to prevent subsequent mobilization of hazardous constituents.

There is a need for improved landfill cover designs. Many conventional designs feature a compacted soil layer, which suffer from desiccation, root and animal intrusion, and other concerns. Geosynthetics, increasingly being used in cover designs, do not address all of the shortcomings of compacted soil layers and can add substantially to the cost of the cover system. Alternative designs such as capillary barriers show promise, but they have not been widely applied and their performance has not been fully demonstrated.

The dry barrier concept is being developed as an additional component in a landfill cover system. A dry barrier is a layer of geologic material that is dried by air flow. Drying a soi! layer creates a barrier to water movement in three ways. First, the drying removes water from the system, intercepting the downward movement of water. Second, drying a soil layer increases its water storage capacity so the soil will tend to retain rather than transmit water. Third, as a soil layer dries, progressively smaller and smaller poresempty and hydraulic conductivity decreases. For example, the hydraulic conductivity of a typical sand may decrease three orders of magnitude as its moisture content is reduced from $20 \%$ to $10 \%$. The coarser a soil layer is, the greater the reduction in hydraulic conductivity as it dries.

Adding a dry barrier will remove some water from a landfill cover system. Every unit of water removed from the cover system is that much less potential leachate generated. To create a dry barrier, air at ambient atmospheric water content is injected into a layer within the cover, water vapor is accumulated as it passes through the layer, and moist air emerges. Because covers typically include multiple, laterally continuous layers with contrasts in material properties, air flow is channeled through relatively coarse, air-permeable layers within the cover.

Both active and passive systems are possible. An active system uses blowers and fans to move air through a high-permeability layer within the cover system. A passive system exploits atmospheric phenomena such as pressure fronts, atmospheric tides, and wind to induce 
air movement through the coarse layer to dry the system. A passive system could be constructed to maximize the exposure of a coarse layer to prevailing winds or to exploit barometric pressure fluctuations. Other passive systems can be envisioned, including wind-powered and thermal vents.

In this report, we consider the application of active dry barriers in landfill cover systems. We selected active systems as a reasonable starting point for the evaluation of the dry barrier technology (DBT). Based on the outcome of this evaluation, passive systems will be considered in subsequent investigations. This report is organized as follows. In Chapter 2, current technology for covering landfills is reviewed, and the shortcomings of conventional technologies are discussed. The dry barrier concept is described further in Chapter 3, including a numerical investigation of air drying a layer within a cover. Chapter 4 contains parametric design analyses, which provide the requirements for air flow and pressure drops to remove sufficient water to achieve proposed design criteria. Equipment specifications and costs for active dry barriers at three western US sites are given in Chapter 5 . Chapter 6 contains brief conclusions regarding our evaluation of an active dry barrier system. 


\subsection{Current Landfill Cover Technology}

Surface covers are mandated for the closure of many types of hazardous waste disposal units, including landfills, surface impoundments, waste piles, and some mine tailings piles. Closure of hazardous and radioactive waste landfills requires the construction of a "lowpermeability" cover over the unit to limit the migration of liquids into the underlying waste (40 CFR 264 and 265, Subpart $N$ ). These landfills must be maintained and monitored for 30 years to ensure that hazardous materials are not migrating from the landfill. Surface impoundments such as holding and settling pits, ponds, and lagoons, which are not completely "clean" upon closure, must be closed as a landfill (40 CFR 264 and 265, Subpart $K$ ). In this case, closure includes removal of liquids, stabilization of hazardous waste, placement of an impermeable cap over the unit, and a 30-year, post-closure maintenance and monitoring program. Waste piles are defined as the accumulation of non-containerized solid waste for treatment or storage. If a waste pile cannot be completely removed or decontaminated, then the unit must be closed as a landfill (40 CFR 264.258 and 265.258). If necessary, sub-surface soils must be stabilized, an impermeable cap placed over the unit, and the site maintained and monitored for 30 years. Tailings fron the mining and milling of uranium are required to be restricted from the environment ( 40 CFR 192). In addition to minimizing infiltration through the tailings, radon. emissions are to be minimized. Uranium tailings piles are covered with a site-specific, multilayer cover. The complete cover is similar to the cover recommended for landfill closure by the Environmental Protection Agency (EPA).

The baseline or conventional cover for the closure of hazardous waste landfills or similar units is defined by an EPA technical guidance document (EPA, 1989). The EPA recommends a multi-layer final cover design composed of three layers with allowance for optional layers. The basic three layers, from top to bottom, are (Figure 1):

- Top Soil Layer-A layer of either vegetation or armored surface and $60 \mathrm{~cm}$ of soil. The vegetation or armored surface is selected to minimize erosion and to promote drainage off the cover. The soil should include at least $15 \mathrm{~cm}$ of topsoil and should not be compacted so as to support vegetation. The soil should be sloped between 3 and $5 \%$.

- Drainage Layer-A layer of either soil or a geosynthetic material that will promote lateral drainage with a lateral slope of at least $3 \%$. If a soil is used, it 


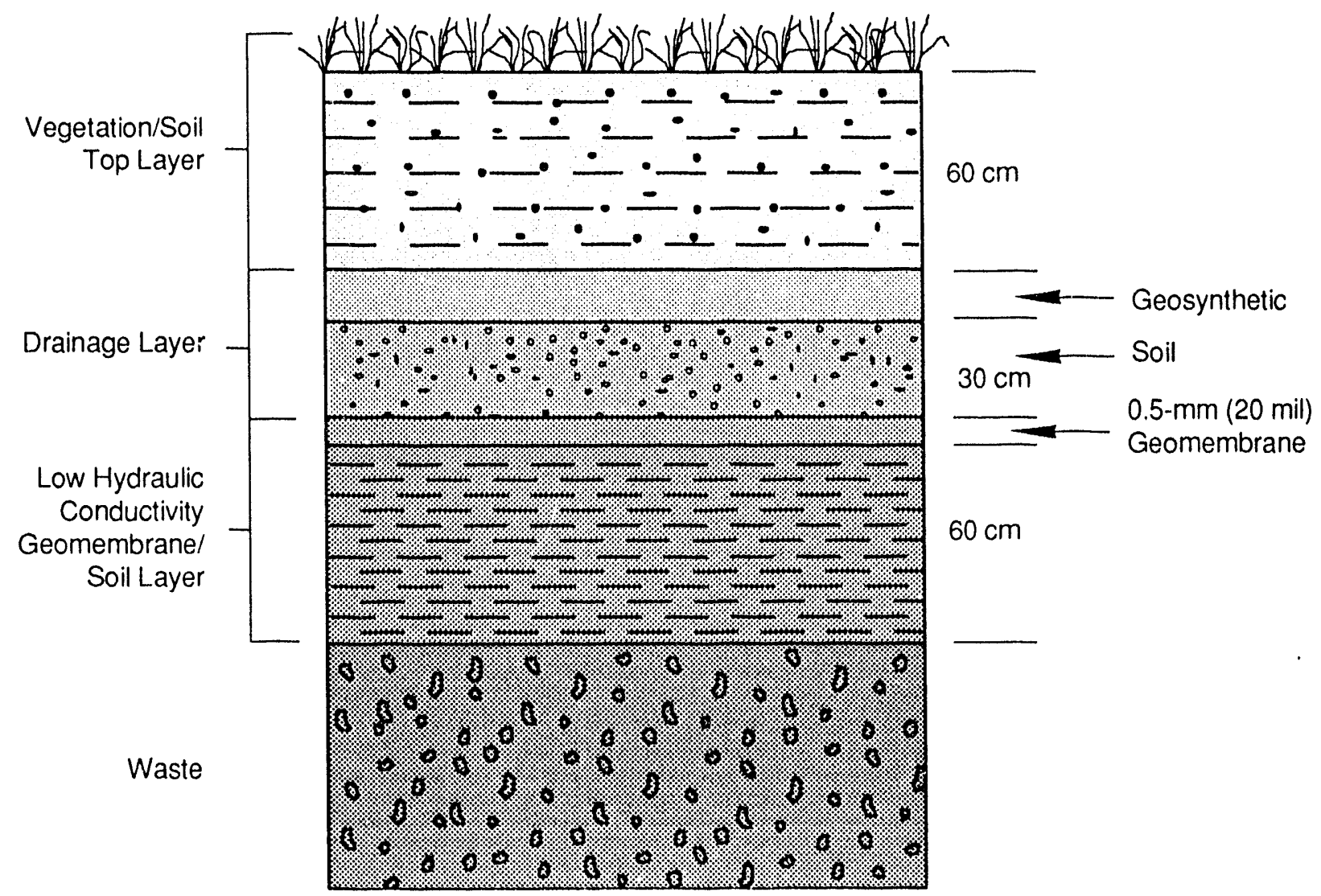

Source: EPA, 1989

Not to Scale

Figure 1. The EPA-recommended design for hazardous waste landfill covers.

should be at least $30 \mathrm{~cm}$ thick and have a minimum hydraulic conductivity of $10^{-2}$ $\mathrm{cm} / \mathrm{sec}$. Geosynthetic materials should have properties equivalent to the soil drainage layer.

- Low-Permeability Layer-A two-component layer to minimize the infiltration of water through the cover into the underlying waste. The layer consists of a geomembrane of at least 20 -mil $(0.5 \mathrm{~mm})$ thickness overlying a $60-\mathrm{cm}$ thick compacted soil layer with a maximum hydraulic conductivity of $10^{-7} \mathrm{~cm} / \mathrm{sec}$. The low-permeability layer should have a slope of at least $3 \%$.

Optional layers include gas-vent layers and biotic barriers. The gas-vent layers are used to intercept waste-generated gases (methane) that may accumulate and become an explosion 
hazard or develop pressures underneath the cover. A biotic barrier, typically a $30-\mathrm{cm}$ thick cobble layer between the top-soil and the drainage layers, is used to protect the cover from intrusion of burrowing animals.

The compacted soil layer is a principal feature of the EPA-recommended designs and has been widely applied to cover many landfills. As experience accumulates with using these layers, shortcomings are becoming increasingly evident. Suter et al. (1993) summarized factors affecting the integrity of a compacted soil barrier, including freeze-thaw effects, shrink-swell effects, erosion, subsidence, root intrusion, and animal intrusion. Suter et al. (1993) conclude that compacted soil layers are unlikely by themselves to be effective long-term barriers. Desiccation is another critical factor affecting compacted soil performance. Once desiccated, a compacted soil layer is likely to crack and become ineffective. Exposure of these layers during construction can result in desiccation even in relatively humid environments such as Wisconsin (Montgomery and Parsons, 1989). In arid environments, desiccation of a compacted soil layer may not stop after the construction phase. Plant roots will seek out the relatively wet layer, removing moisture and leaving root paths (Hakonson, 1986). Depending on the type and thickness of the materials that overlie the compacted soil layer, moisture within the soil layer may be lost to the adjacent, drier soils. Geosynthetic clay liners (GCLs) are replacing compacted soil liners for some applications. A GCL consists of a thin, dry, clay layer confined between geotextile materials. A GCL can have some performance advantages, but has not been widely applied.

There is increasing reliance on a geomembrane overlying the compacted soil liner or GCL to reduce or limit downward water movement. The geomembranes, which are typically constructed of polyethylene, frequently develop a number of flaws during construction such as tears, punctures, and open seams. Geomembranes do not accommodate large amounts of the eventual subsidence and settlement many landfills experience (Oweis, 1989). Another concern with geomembranes is that they may degrade with time, a particular concern for mixed-waste sites.

The EPA technical guidance permits alternative designs if they can be demonstrated to be equivalent in performance to the generic design. Los Alamos National Laboratory (LANL) has designed, installed, and tested numerous cover systems designed specifically for the western United States. These designs emphasize capillary barriers and utilize site-specific vegetation schemes. A schematic illustration of a capillary barrier is given in Figure 2. 


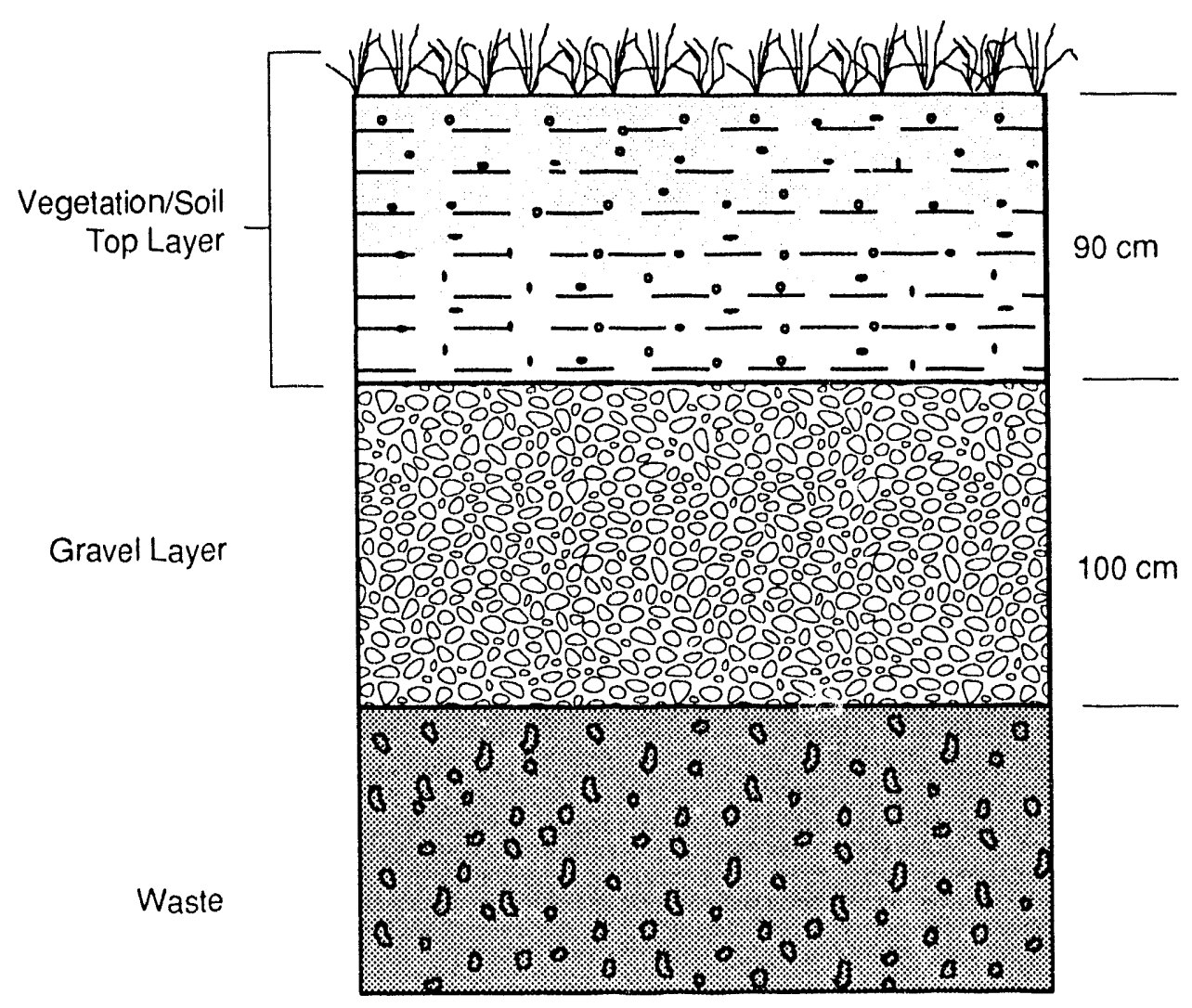

Not to Scale

Figure 2. Basic capillary barrier design.

The contrasting materials of the fine-over-coarse arrangement serve as a barrier to downward flow. Water is held in the fine layer by capillary forces and is available for evapotranspiration or lateral drainage. Capillary barriers can be effective as long as the water content of the fine layer is not sufficient to permit breakthrough into the coarse layer. Some of the capillary barriers installed and tested at LANL have permitted breakthrough and indicate the designs should be modified somewhat (Hakonson, personal communication). At the Department of Energy's (DOE's) Hanford, WA, operation, multi-layered engineered covers have been designed and tested (Wing and Gee, 1990). These barriers employ design features similar to the LANL designs: layers of soils with contrasting properties and natural vegetation. These alternative designs may offer advantages in terms of lower cost and possibly longer effective life, but there are insufficient data to draw firm conclusions about their utility. 
It is inevitable that all covers permit some water movement through them, and a totally impermeable cover is not achievable or verifiable. For some applications, the amount of water moving through a cover may be excessive. The EPA's Hydrologic Evaluation of Landfill Performance (HELP) computer model is often used to estimate leakage through a cover. In model simulations of a cover performance in Santa Maria, CA-an environment that receives about the same precipitation as Albuquerque, NM-the HELP model predicts that $1 \%$ to $5 \%$ of the precipitation moves through a cover that is designed to meet the EPA guidance (EPA, 1991). It is important to bear in mind that these simulations assume ideal performance of all cover components. Degradation of the cover with time will result in increasing amounts of percolation through the cover.

Large precipitation events-either as rapid snowmelt or high-intensity rainfall-tend to be particularly stressful to landfill covers. In a demonstration of several designs of various cover designs at Hill Air Force Base (ABF) near Salt Lake City, percolation through the covers occurs principally during late winter and spring (February to May) snowmelt when evapotranspiration is low and springtime snowmelt and rainfall provide a strong driving force for downward percolation (Hakonson et al., 1992). A similar conclusion was reached based on field measurements of landfill cover designs studied at LANL (Nyhan et al., 1990). In a more humid environment, Weeks et al. (1992) demonstrated that high-intensity rainfall provided the greatest potential for inducing percolation through a landfill cover.

Some of the design considerations for landfill covers are highlighted by the field study and analysis of various landfill cover designs at Hill AFB. Hakonson et al. (1992) installed and monitored four cover designs. The designs tested were a control (soil) cover, two alternative designs using capillary barriers and selected vegetation, and a generic cover based on general EPA recommendations. The cover plots were instrumented to measure precipitation, runoff, lateral drainage, changes in soil storage, and percolation through the liner. Evapotranspiration was calculated from the other measured values by employing a simple water-balance. Results of the study are summarized in Table 1, adapted from Paige et al. (1993). The "best" cover depends on which performance criterion is the most important. For example, the simple soil cover was the least expensive but permitted the most percolation. The EPA cover allowed little percolation but is relatively expensive. These results illustrate that cover systems could be improved by relatively inexpensive engineered techniques to reduce downward movement of water. 
Table 1. Observed Results for Hill AFB Study Over a Period of 45 Months (from Paige et al., 1993)

\begin{tabular}{|c|c|c|c|c|}
\hline \multirow[b]{2}{*}{ Design/Criterion } & \multicolumn{4}{|c|}{ Trench Cap Designs } \\
\hline & $\begin{array}{c}\text { Control } \\
\text { Cap }\end{array}$ & $\begin{array}{c}\text { EPA } \\
\text { RCRA }\end{array}$ & $\begin{array}{c}\text { Los } \\
\text { Alamos } 1\end{array}$ & $\begin{array}{c}\text { Los } \\
\text { Alamos } 2\end{array}$ \\
\hline Runoff $(\mathrm{cm})^{+}$ & 1.40 & 12.05 & 5.18 & 3.50 \\
\hline $\begin{array}{l}\text { Sediment Yield } \\
(\mathrm{Kg} / \mathrm{ha})\end{array}$ & 118.7 & 76.7 & 4.5 & 4.8 \\
\hline ET $(\mathrm{cm})$ & 27.37 & 28.80 & 24.25 & 33.99 \\
\hline Percolation $(\mathrm{cm})^{*}$ & 14.74 & 0.13 & 6.82 & 7.28 \\
\hline Cost $(\$ M / h a)$ & 0.12 & 4.9 & 2.5 & 2.5 \\
\hline \multicolumn{5}{|c|}{$\begin{array}{l}\text { + includes lateral flow where applicable. } \\
\text { * percolation out of trench cap and into waste storage layer. }\end{array}$} \\
\hline
\end{tabular}




\subsection{Incorporating a Dry Barrier in a Cover System}

Incorporating a dry barrier into a cover design offers two potential advantages: 1) reduced water movement through the cover, and 2) more efficient, less costly cover design. Water removal with a dry barrier essentially adds an additional component to the water balance of the cover. A dry barrier is readily incorporated into the cover designs discussed previously. Air can be circulated through the drainage layer or the biotic barrier layer because these layers have relatively high air permeabilities. In addition to drying the relatively coarse layers, some moisture will be removed from the overlying soil layer. In this way, the cover can be conditioned to accommodate the springtime percolation events that tend to result in cover failure, especially in relatively arid environments.

A dry barrier can offer economic advantages in the design of a landfill cover. It can be expensive to build a landfill cover system at a $3 \%$ to $5 \%$ slope to facilitate drainage. By moving some of the moisture in a vapor phase, it may be possible to reduce the slope and, consequently, the amount of material required to achieve the slope. Similarly, the thickness of the uppermost soil layer may be reduced as its requirements for water storage are lessened.

\subsection{WATER REMOVAL IN A DRY BARRIER COVER SYSTEM}

The gas in the pore spaces of unsaturated soils remains nearly saturated with water vapor until the soil essentially becomes completely dry. Drying a soil layer with air is possible because atmospheric air generally contains less water vapor than soil pore gas at equilibrium in an unsaturated soil. When an unsaturated soil is flushed with atmospheric air, the flowing air will remove water vapor, and additional pore water will evaporate.

A useful measure of the ability of atmospheric air to dry a soil layer is specific humidity. The specific humidity is the ratio of the mass of water vapor $\left(\mathrm{m}_{\mathrm{v}}\right)$ to the entire mass of moist air $\left(m_{2}\right)$ as shown by Equation 1 below.

$$
\mathrm{W}=\frac{\mathrm{m}_{\mathrm{v}}}{\mathrm{m}_{\mathrm{a}}}
$$

The specific humidity can be calculated from relative humidity and temperature. The maximum specific humidity is constant for a given temperature and is available in handbooks. The 
difference between the measured and maximum specific humidity represents the potential of the air to evaporate more water, i.e., its drying potential $\left(\mathrm{W}_{\mathrm{DP}}\right)$, where $\mathrm{W}_{\mathrm{DP}}=\mathrm{W}_{\max }-\mathrm{W}$. In Figure 3 , the average ambient and maximum specific humidities of Albuquerque air are given and the drying potential identified.

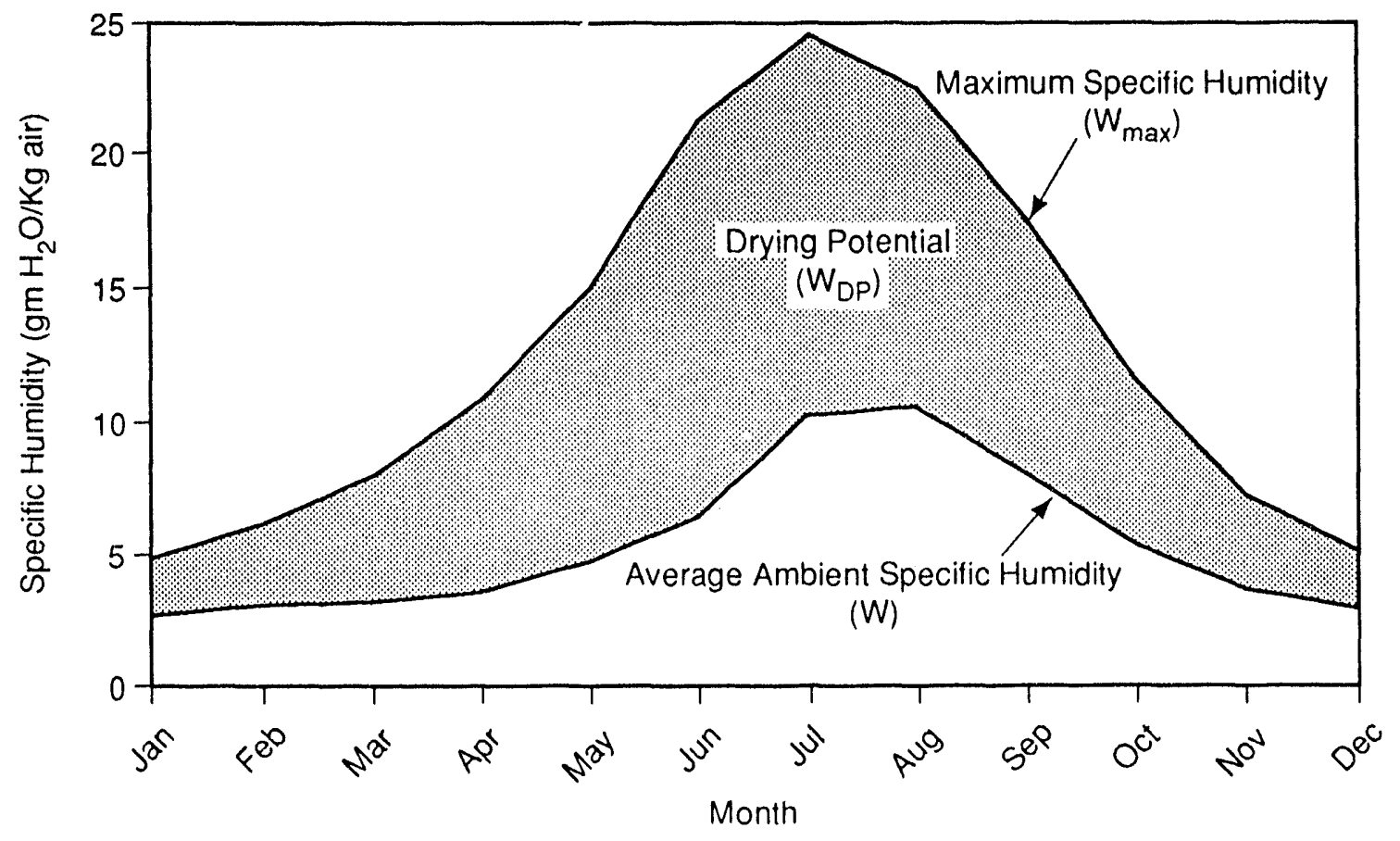

TR1.6621.69.0

Figure 3. Drying potential of Albuquerque air in terms of specific humidity.

The earthen materials within a cover system have a large thermal mass. If we assume that the cover remains at a constant value of $13^{\circ} \mathrm{C}$-the average annual temperature of soils near Albuquerque-then the air passing through the cover will assume this temperature if the flow path is sufficiently long and its velocity is sufficiently low. In this case, the maximum specific humidity remains constant at approximately $11 \mathrm{gm} \mathrm{H}_{2} \mathrm{O} / \mathrm{Kg}$ air. Thus, the drying potential of the air is reduced in the summer and increased in the winter (Figure 4).

The mechanisms by which water movement is induced by air flow in a fine-over-coarsecover system is illustrated in Figure 5. Because the coarse layer is so permeable to air, the vast majority of the advective flow will occur in this layer. The coarse layer will be dried by the evaporation of pore water and its removal by advective flow. Some water will also be removed from the fine layer. As the coarse layer dries, a water potential gradient develops. The water potential gradient will induce unsaturated liquid flow from the fine to the coarse layer and also 


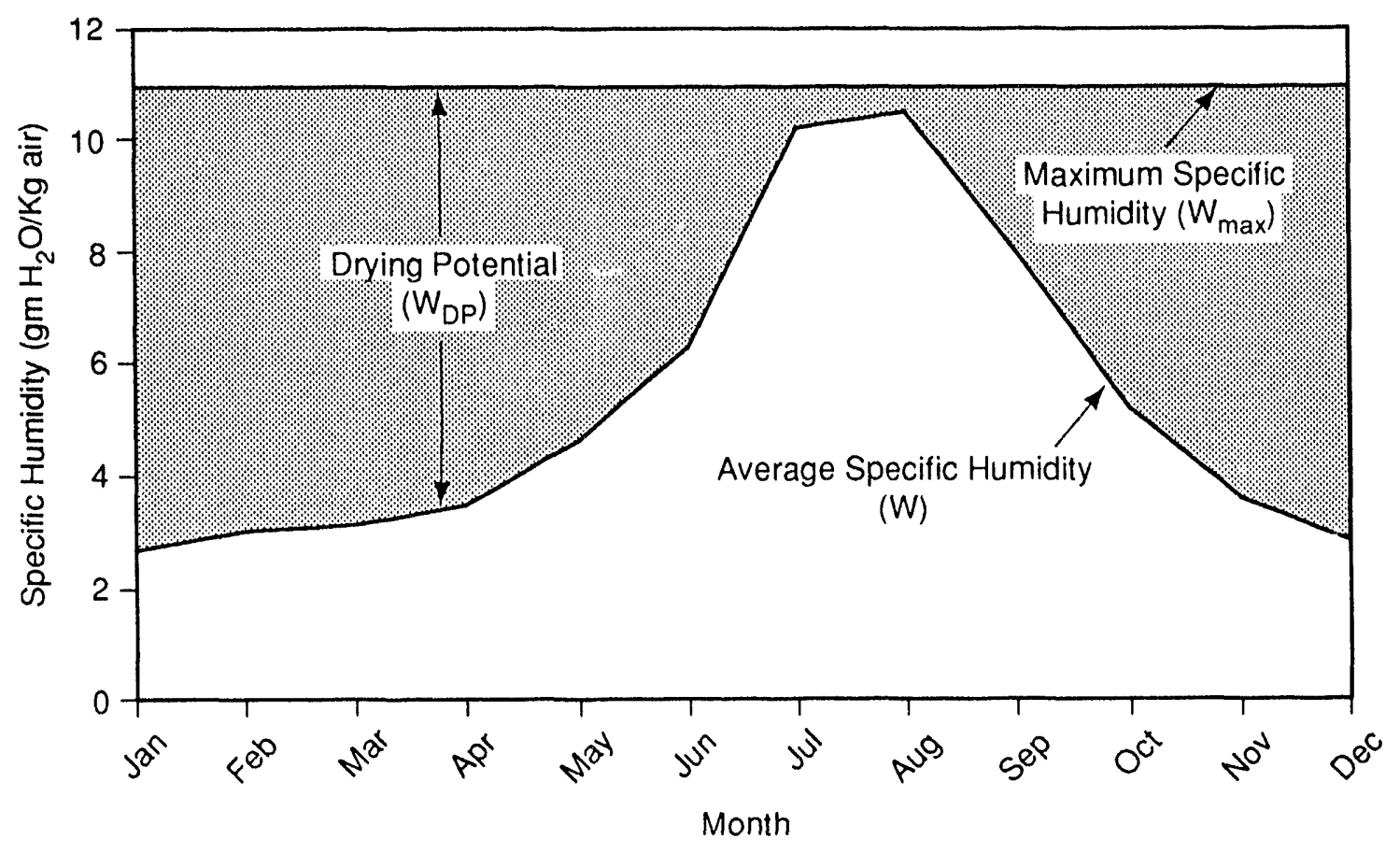

Figure 4. Drying power of air equilibrated with $13^{\circ} \mathrm{C}$ soil in terms of specific humidity.

will induce water vapor diffusion from the fine to the coarse layer. Some advective air flow also occurs in fine layers. The lateral advective air flow in the fine layer will be many orders of magnitude less than that in the coarse layer due to the differences in their permeabilities. Vertical air flow occurs in the fine layer due to pressure gradients between the atmosphere and the actively pumped coarse layer.

\subsection{ANALYSIS OF DRY BARRIER PERFORMANCE}

We performed a numerical analysis of a typical landfill cover design to investigate the mechanisms of water movement induced by air flow. An illustration of the geometry evaluated is given in Figure 6. The numerical simulations utilized the drainage layer as the dry barrier layer. The drainage layer is typically underlain by a geomembrane that rests on top of a claybased layer. This geomembrane will isolate the air-dried layer from the clay-based layer, which is important because drying the clay would reduce its performance. For our purposes, we considered the geomembrane as being impermeable and therefore only considered the top three layers of the complete multi-component design. 


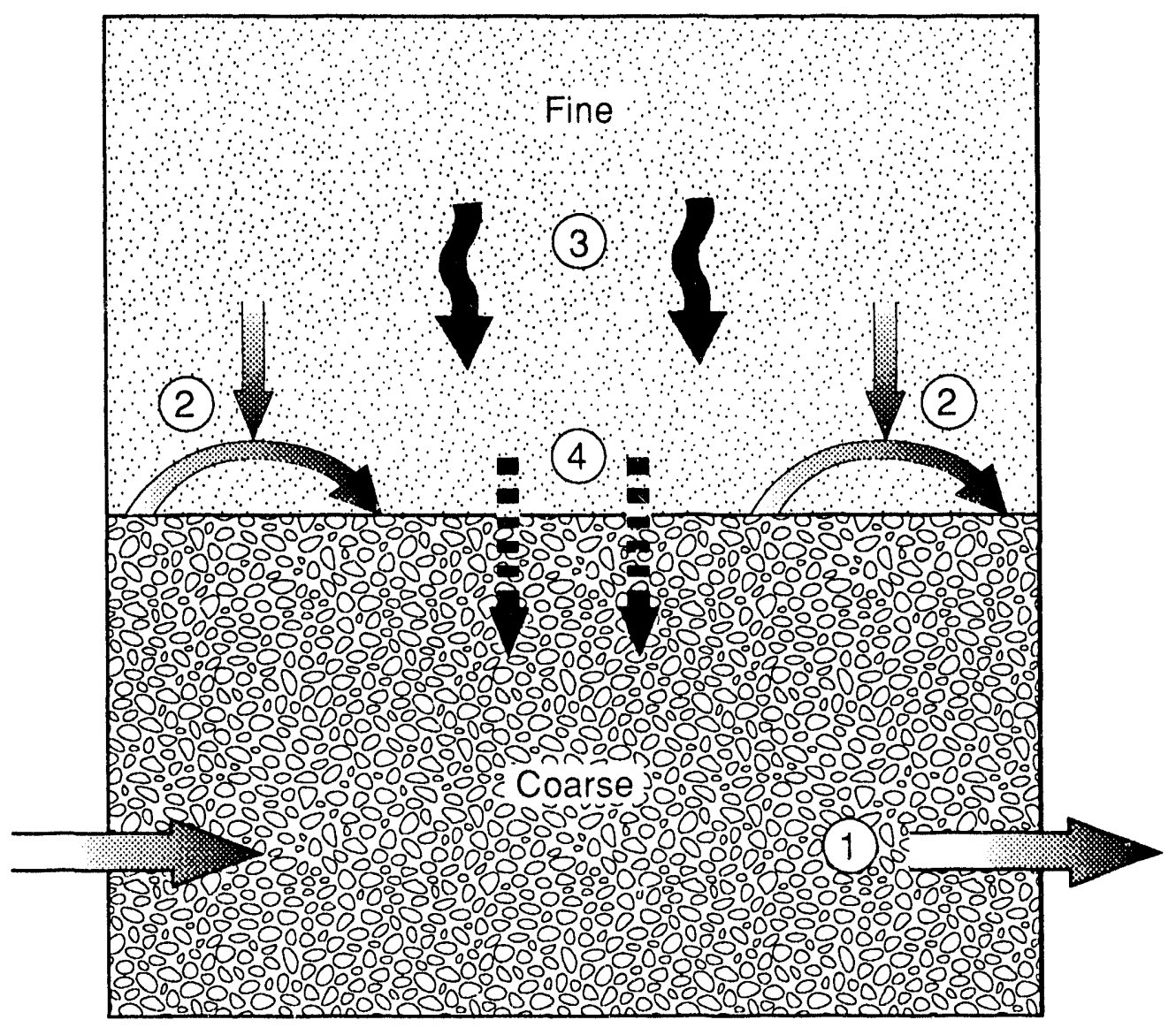

(1) Evaporation and advection in coarse layer.

(2) Evaporation and advection in fine layer.

(3) Liquid water unsaturated flow.

(4) Water vapor diffusion from fine to coarse layer.

TRI.6621.78.0

Figure 5. Mechanisms of water movement induced by air flow in a fine-over-coarse-cover system. 


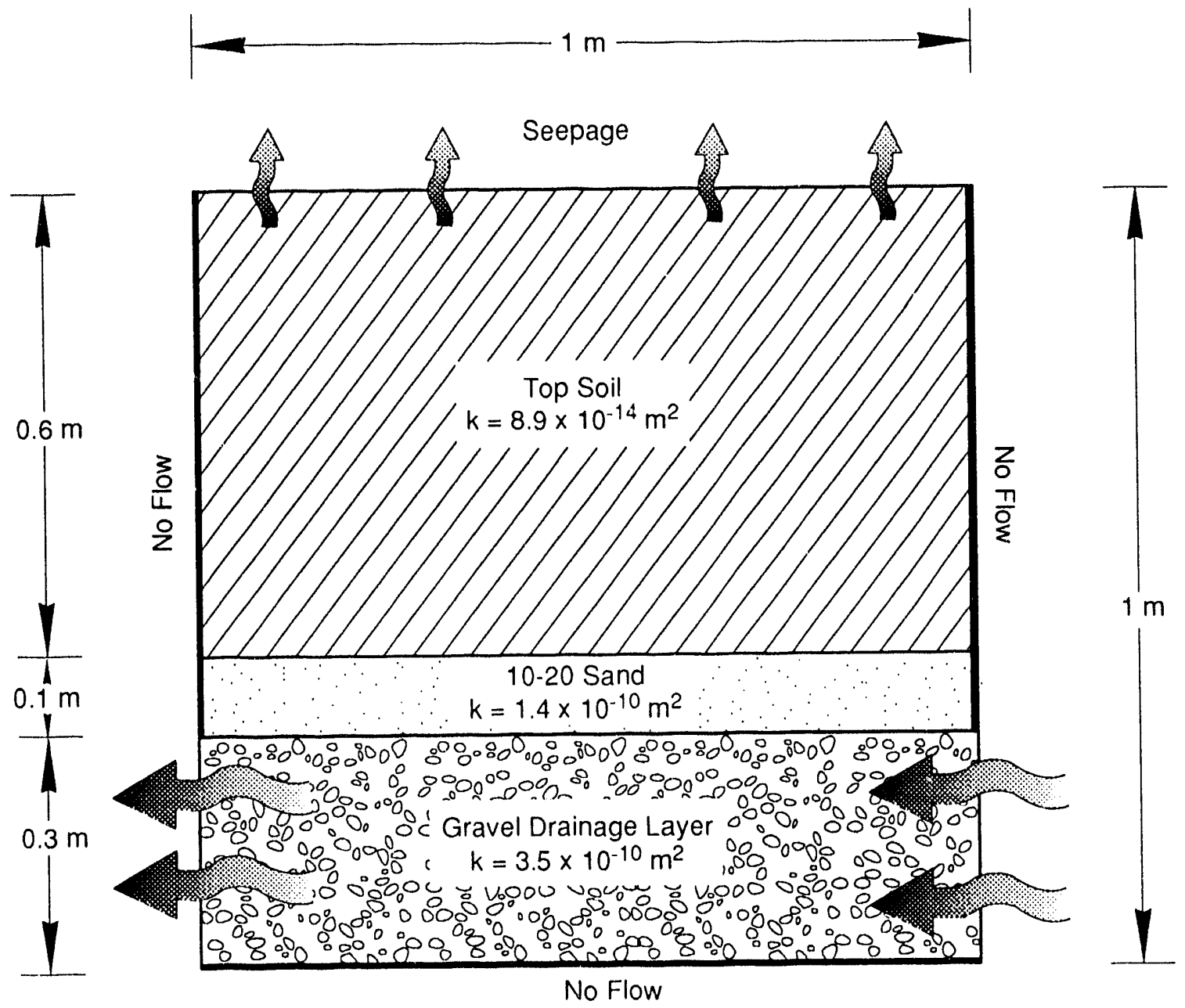

TRI.6621.61.0

Figure 6. Model geometry and boundary conditions for numerical simulations of the upper three layers of a cover system.

The simulations were conducted using the TOUGH2 numerical code. TOUGH2 is capable of simulating multi-dimensional coupled flow of multi-phase fluids in porous and fractured media (Pruess, 1991). The vertical dimensions of the different cover elements are consistent with the EPA guidelines (EPA, 1991). The horizontal dimension of $1 \mathrm{~m}$ was selected to simulate a "unit width" of the cover. The model grid consists of uniform cells with dimensions of $0.1 \mathrm{~m}$ by $0.1 \mathrm{~m}$ by $0.01 \mathrm{~m}$. As configured, the grid is essentially a two- 
dimensional cross section through a segment of an EPA cover. The physical properties of model parameters employed in the simulations were based on the characteristics of the materials used in an EPA cover (Appendix A).

The boundary conditions employed in the modeling included specified pressure, temperature, and air-phase mass fractions. A no-flow boundary was employed at the base of the gravel layer to simulate the presence of an impermeable liner below the pea-sized gravel. Horizontal and vertical air flow through the cover was induced by establishing various horizontal and vertical pressure gradients across the gravel layer and between the gravel and the ground surface.

The vertical boundaries of the topsoil and the sand were simulated as no-flow boundaries. This condition was employed so that the effect of air flow in the gravel on the water content of the overlying layers could be independently assessed. The ground surface and vertical boundaries of the gravel layer were simulated as seepage faces by specifying a capillary pressure of zero and perfect mobility for both phases. This condition permits the flow of both water and air across these boundaries. The locations of the model boundaries are shown in Figure 6 .

The initial conditions were established by model simulations of drainage from conditions of near saturation throughout the entire cap to an equilibrium distribution of soil water content at ambient, static air-pressure conditions. A typical distribution of resulting initial water phase saturations within the landfill cover is shown in Figure 7. As can be observed, the water content of the topsoil layer increases from a relative saturation of approximately 0.8 at the ground surface to greater than 0.95 at its base. The water content of the sand and the upper $0.2 \mathrm{~m}$ of the gravel layer is slightly greater than residual saturation. However, the base of the gravel is close to being saturated due to the presence of the impermeable boundary at its base.

A series of simulations was conducted with various horizontal and vertical pressure gradients and relative humidities of the influent airstream. The vertical gradient, a result of the difference between the pressure in the dry barrier layer and atmosphere, will drive water vapor flow and perhaps some liquid water redistribution in the fine layer. The horizontal gradient across the coarse layer will induce air flow, evaporation of water, and drying of the coarse layer. Values of $25,50,75$, and $100 \%$ relative humidity of the inlet air were assumed to simulate various climatic conditions. (For isothermal conditions, relative humidity is directly related to specific humidity.) 


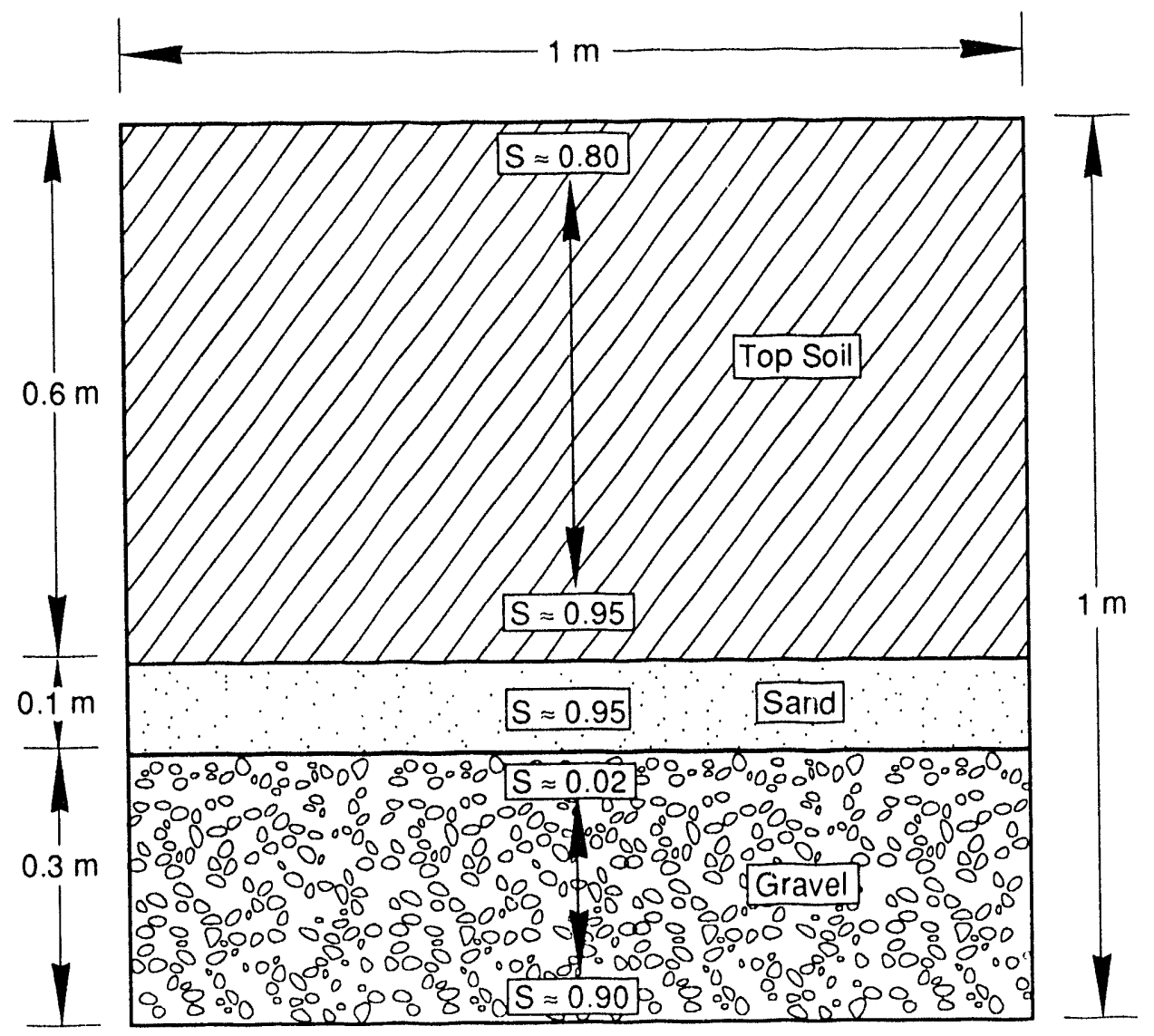

Note: $\mathrm{S}=$ Saturation

Figure 7. Initial saturations due to gravity drainage in the upper three layers of a cover system prior to establishing air flow through a coarse layer.

The model simulation results indicated that vertical pressure gradients have very little effect on the reduction in moisture content within the cover. This result is directly related to the relatively low permeability of the topsoil present in the uppermost layer of the landfill cover. The influence of the horizontal air pressure gradient is much more significant.

The effects of varying horizontal pressure gradients under conditions of low relative humidity on the fraction of initial mass remaining in the cover over a one-year simulation period are presented in Figure 8. Increases in the horizontal pressure from 25 to $50 \mathrm{~Pa} / \mathrm{m}$ results in virtually the complete removal of water within the gravel layer within a 6-month time period. Increasing the gradient under these conditions to $100 \mathrm{~Pa} / \mathrm{m}$, decreases the drying time to approximately 3 months. The moisture of the topsoil layer is also reduced; significant drying of the topsoil layer begins to occur only after the moisture content of the gravel layer has been substantially reduced. 
The numerical simulations reveal that air flow in the coarse layer induces some water movement in the fine layer. The removal of water by evaporation near the fine/coarse layer interface reduces the local water content. When the local hydraulic head decreases, a downward liquid water pressure gradient is established, and water moves toward the fine/coarse layer interface and becomes available for evaporation. This result is important because it suggests the fine-layer water content may be moderated by air flow in the coarse layer.

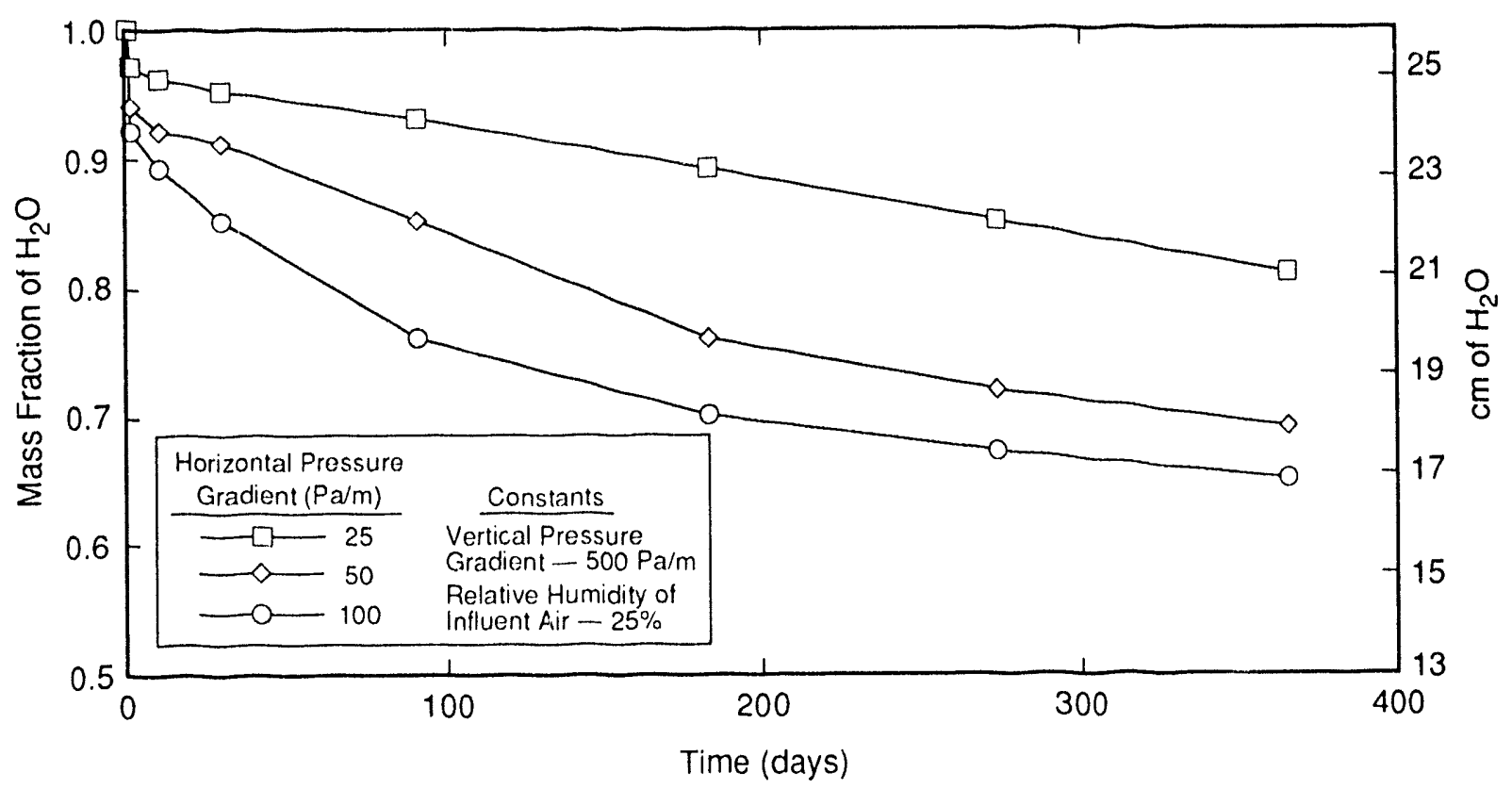

TRI-6621-80.0

Figure 8. Simulated water removal as a function of time. 


\subsection{Analysis of Landfill Cover System Applications}

We performed a design analysis of an active dry barrier to quantify its potential as a component in a landfill cover system.

\subsection{DESIGN CRITERIA FOR DRY BARRIER IN A COVER SYSTEM}

We developed two criteria by which to evaluate the potential applicability of DBT. Criterion 1 was the removal of $10 \%$ of annual precipitation, and Criterion 2 was the removal of moisture equivalent to the precipitation during the most vulnerable month.

\section{Criterion 1: Remove $10 \%$ of annual precipitation.}

We propose the removal of $10 \%$ of the annual precipitation as the criterion for a "significant" effect of a dry barrier on the annual water balance. This value, although largely arbitrary, will make a substantial difference in the performance of a landfill cover. At the same time, this criterion recognizes that a dry barrier will be an incremental improvement to the landfill cover performance and should not be required to remove all precipitation.

The $10 \%$ criterion represents an appreciable portion of the water that percolates through a typical cover. The capillary barriers emplaced and monitored at Hill AFB, UT, produce leachate equivalent to about $20 \%$ of the annual precipitation (Hakonson et al., 1992); in this case, the $10 \%$ criterion represents one-half of the production through the landfill. In a sensitivity analysis of the EPA's HELP model, an average of $16 \%$ of the annual precipitation is assumed to leak through the uppermost layers of a cover into the drainage layer. Depending on the design and assumed performance, the HELP model predicts from $<1$ to about $50 \%$ of the annual precipitation that percolates through a complete cover system. These analyses indicate that $10 \%$ of the annual precipitation can represent a large percentage of the water that percolates through the cover system. While a $10 \%$ criterion has been assumed for this discussion, the criterion could be raised or lowered to equal any specified percolation rate.

This design criterion will be dependent on the specific location because different sites have different rates of precipitation. We have selected three western US locations to evaluate the application of a dry barrier layer: Albuquerque, Los Alamos, and Salt Lake City. These locations have varied climates representative of the western US, and have DOE and/or 
Department of Defense (DoD) sites, which may benefit from DBT. Precipitation data for these three locations are given in Table 2.

Criterion 2: Remove moisture equivalent to the precipitation during the most vulnerable month.

In arid and semi-arid environments, the greatest potential for failure of landfill covers occurs during late winter and early spring when evapotranspiration is virtually nonexistent due to the lack of active vegetation and snowmelt and rainfall are high. The highest potential percolation therefore occurs during this time period. A significant improvement to a cover system would be realized if the dry barrier could be used to remove water in the cover before or during these vulnerable periods. Therefore, as a general water removal criterion we propose to remove water from the system at a rate equal to the average monthly precipitation rate during these vulnerable periods.

This design criterion is also location specific. The months of maximum precipitation during the time when we expect no evapotranspiration at the three locations are given in Table 2. The covers will be evaluated at conditions that correspond to near-field capacity. That is, the initial water content of each layer will be at a value that represents imminent drainage under gravity conditions. By beginning at these conditions, we will evaluate how well a dry barrier can restore a cover system poised to allow breakthrough and lateral drainage or vertical infiltration. These conservative assumptions represent a severe initial condition because at lower water contents, the cover is in less jeopardy of failure.

The design criteria are summarized in Table 3. The second design criterion is considerably more stringent than the first. The applicability of the design criteria will be discussed further later in this report.

Table 2. Precipitation Data for Three Western US Sites

\begin{tabular}{lccc}
\hline Location & $\begin{array}{c}\text { Annual } \\
\text { Precipitation } \\
(\mathrm{cm})\end{array}$ & $\begin{array}{c}\text { Month of Highest } \\
\text { Potential Percolation }\end{array}$ & $\begin{array}{c}\text { Precipitation } \\
\text { During this } \\
\text { Month } \\
(\mathrm{cm})\end{array}$ \\
\cline { 2 - 4 } Albuquerque & 22.6 & Dec & 1.27 \\
Los Alamos & 47.6 & Mar & 3.10 \\
Salt I ake City & 41.1 & Mar & 4.85 \\
\hline
\end{tabular}


Table 3. Design Criteria

\begin{tabular}{|c|c|c|}
\hline Location & Criterion 1 & Criterion 2 \\
\hline Albuquerque & $2.26 \mathrm{~cm} / \mathrm{yr}$ & $1.27 \mathrm{~cm} /$ month \\
\hline Los Alamos & $4.76 \mathrm{~cm} / \mathrm{yr}$ & $3.10 \mathrm{~cm} /$ month \\
\hline Salt Lake City & $4.11 \mathrm{~cm} / \mathrm{yr}$ & $4.85 \mathrm{~cm} /$ month \\
\hline
\end{tabular}

\subsection{DESIGN ANALYSIS OF A DRY BARRIER COVER}

We used a simple model of a dry barrier to conduct parametric design calculations. The configuration we considered consisted of a 100 -cm-thick fine layer overlying a 30-cm-thick coarse layer, typical components of a capillary barrier.

A plan view of the dry barrier basic design unit we considered is illustrated in Figure 9. Two perforated pipes (buried in the coarse layer) are separated by some distance. One line employs a positive pressure to flow ambient air into the cover system; the other line is under a vacuum to remove air laden with water vapor from the cover system. There are two ways to

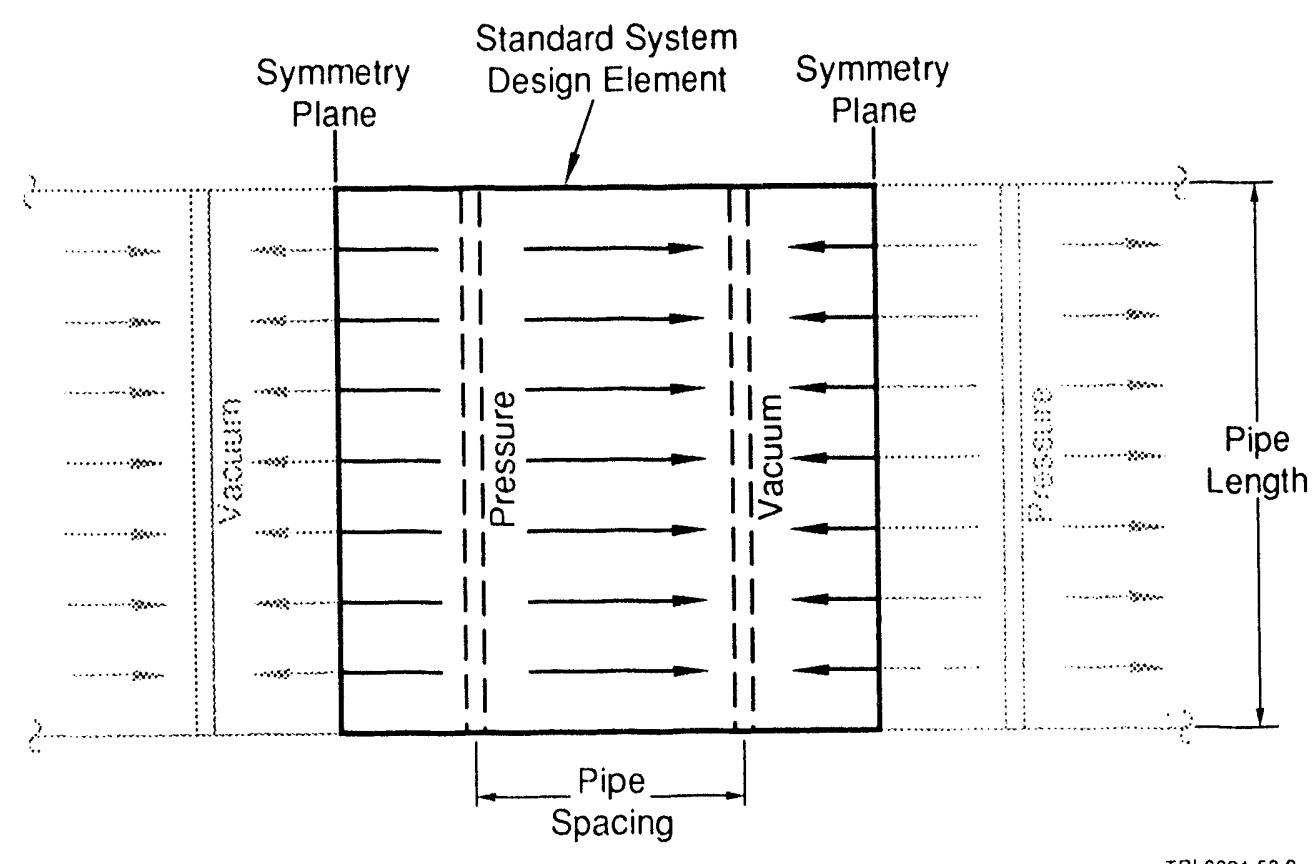

Figure 9. Plan view of a dry barrier design unit showing piping configuration in the coarse layer. 
achieve the desired aerial coverage with a dry barrier. One way is to determine an optimal size of a dry barrier design unit and apply the number of units required to achieve the coverage. The other approach is to increase the size of the unit so it achieves the areal coverage desired.

Our simple model assumes water is removed from the cover system only by advective air flow in the coarse layer. This approach is conservative in that no credit is taken for water movement in the fine layer. We assume steady-state, isothermal, single-phase flow of a compressible fluid (air) between the injection and withdrawal lines. From a modification of a one-dimensional form of Darcy's law, we estimated flow rates for various permeabilities and differential pressures. The amount of water in the form of water vapor, which is removed by the calculated air flow, is a function of the specific humidity of the inlet (ambient) air and the flow rate through the coarse layer. For these calculations we assume a $50 \%$ gain in specific humidity of the inlet air as it passes through the coarse layer, as shown in Equation 2 below.

$$
\mathrm{W}_{\text {out }}-\mathrm{W}_{\text {in }}=0.5 \mathrm{~W}_{\max } \text {. }
$$

where $\mathrm{W}_{\text {out }}$ is outlet specific humidity, $\mathrm{W}_{\text {in }}$ is inlet specific humidity, and $\mathrm{W}_{\max }$ is maximum specific humidity. If the outlet and inlet air temperatures are equal, we can express Equation (2) in terms of relative humidity (rh)

$$
\mathrm{rh}_{\text {out }}-\mathrm{rh}_{\mathrm{in}}=50 \% \text {. }
$$

where $r h_{\text {out }}$ is outlet relative humidity and $r h_{\text {in }}$ is inlet relative humidity. Because the mass transfer of the water into the moving air stream (evaporation) occurs over a relatively short distance relative to the system geometry, we could expect the outlet air to be nearly saturated with water vapor, i.e., $\mathrm{rh}_{\mathrm{out}}=100 \%$. This assumption implies that the relative humidity of the inlet air is a constant $50 \%$. Because the average relative humidity in the western US is less than $50 \%$, this assumption is conservative relative to site-specific relative humidity. Calculations using the above simple model compared favorably with the numerical results of the previous section.

The dimensions of the design unit have a direct and important impact on the analyses. Fortunately, there are simple scaling relationships can explain system behavior. If the pipe length is increased, then the air-flow and water-removal rates will be proportionally increased. If the pipe spacing is increased, the air-flow and the volumetric water-removal rates decrease proportionally. It can be shown that if the pipe-length-to-pipe-spacing ratio is held constant, then the air-flow rate and the volumetric water-removal rate will be constant (for a given pressure drop and permeability). The analyses that follow are applicable to a pipe-length-topipe-spacing ratio of two. 
It is convenient to express the amount of water removed from a landfill cover in terms of $\mathrm{cm}$ of water. These units are commonly used when referring to rainfall, leachate production, or other components of the water balance of a landfill system. To derive this value, the volumetric water removed is divided by the area from which it is removed

$$
\text { Water }(\mathrm{cm})=\frac{\text { Volume of water }\left(\mathrm{m}^{3}\right)}{\text { Area }\left(\mathrm{m}^{2}\right)} \times \frac{100 \mathrm{~cm}}{1 \mathrm{~m}} .
$$

The rate of moisture removal in the coarse layer is given as a function of the coarse-layer permeability are given in Figure 10. The range of permeabilities considered includes those for top soil to coarse gravel (Appendix A). Also identified are the corresponding volumetric flow rate of air and differential air pressure required to produce this rate of water removal. The water-removal rate given in Figure 10 is for a dry barrier system covering a hectare $\left(10^{4} \mathrm{~m}^{2}\right)$. To convert this result to any other dry barrier configuration with a pipe-length-to-pipe-spacing ratio of 2 (Figure 9), the following equation is used.

$$
\text { water removal rate for area } \mathrm{A}=\frac{\text { water removal rate for hectare }}{\left(\frac{\text { Area } \mathrm{A}}{10,000}\right)} \text {. }
$$

The most applicable portion of Figure 10 for our purposes is the low differential pressure and high permeability range. In Figure 11, the differential pressure range is limited to $200 \mathrm{~cm}$, and the permeability is representative of fairly coarse materials. We restrict our consideration to a $200-\mathrm{cm}$ differential pressure to avoid damaging the cover with a greater pressure. In addition, this pressure drop is well within the performance capability of commercially available equipment. The greater the permeability, the higher the flow rate for a given differential pressure. For our calculations, the air-flow rate is directly proportional to the water-removal rate. The maximum coarse-layer permeability achievable is unknown, but permeabilities in excess of $10^{-7} \mathrm{~m}^{2}$ have been reported (Sherard et al., 1984). The values in Figure 11 correspond to a range of soils from coarse sand to gravel.

The results presented in Figure 11 indicate that it is possible to have an air-flow rate sufficient to remove large quantities of water from the coarse layer. The results are considered with respect to the design criteria in Figure 12. The equipment and costs to achieve these criteria are given in Chapter 5 .

The preceding calculations are baseo on water removal by evaporation and water vapor advection in the coarse layer. Once all of the water in the coarse layer is removed, the amount 


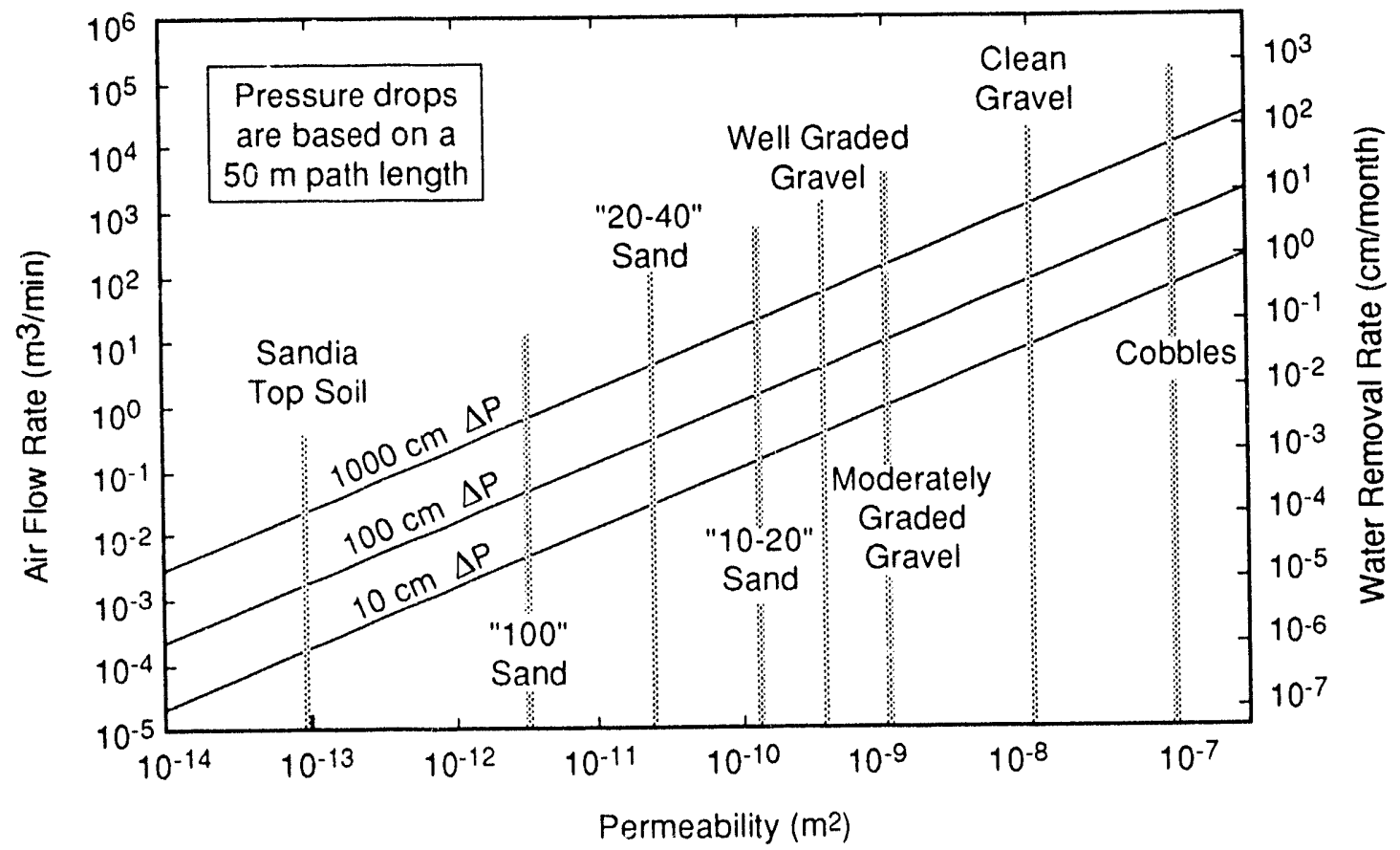

TR1.6621.55.0

Figure 10. Water-removal rates for various permeabilities, flow rates, and pressure drops for a hectare-sized dry barrier with a pipe-length-to-pipe-spacing ratio of 2 .

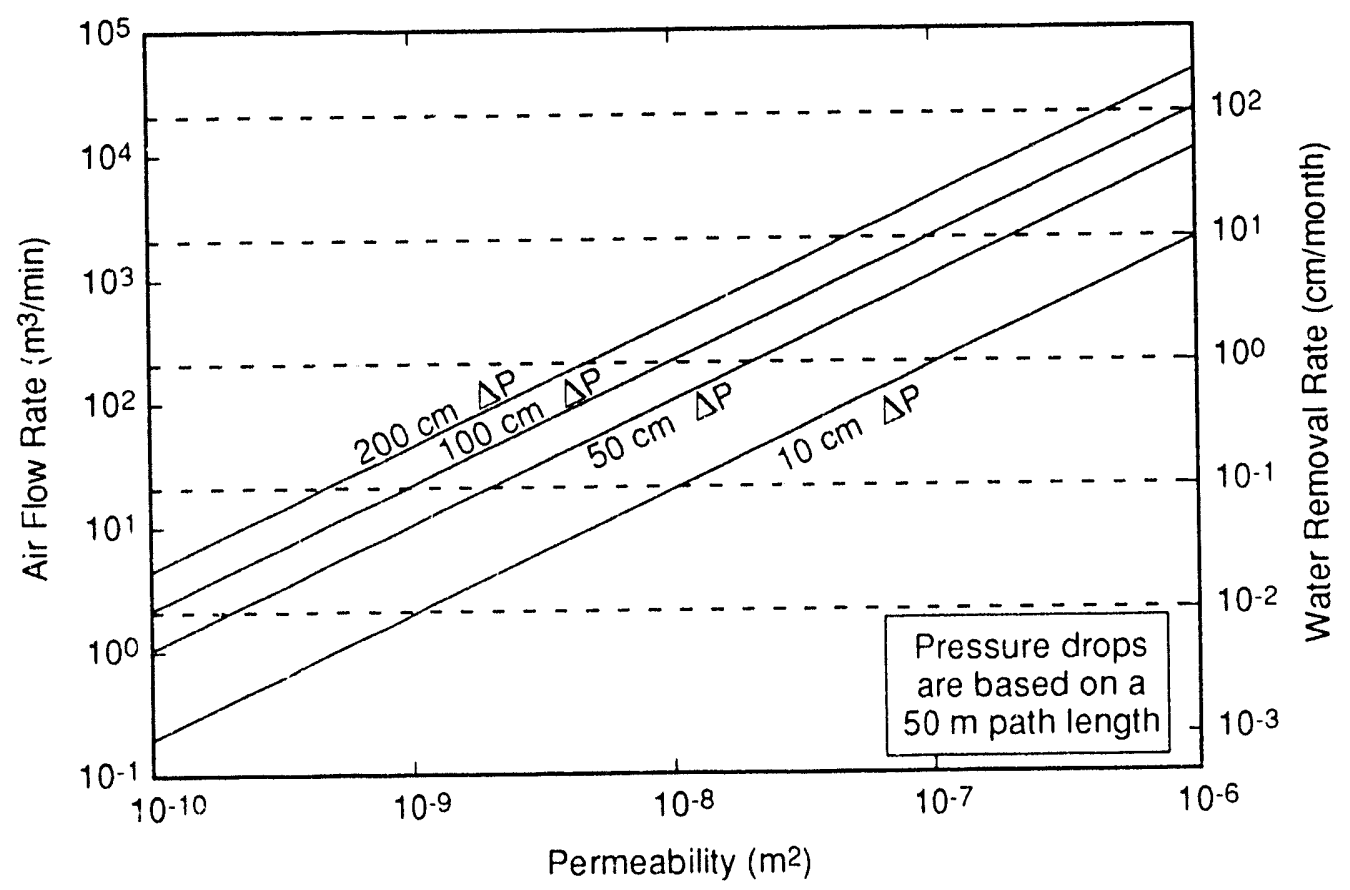

TR1.662.1.56.0

Figure 11. Water-removal rates for a limited range of permeabilities and pressure drops for a hectare-sized dry barrier with a pipe-length-to-pipe-spacing ratio of 2 . 


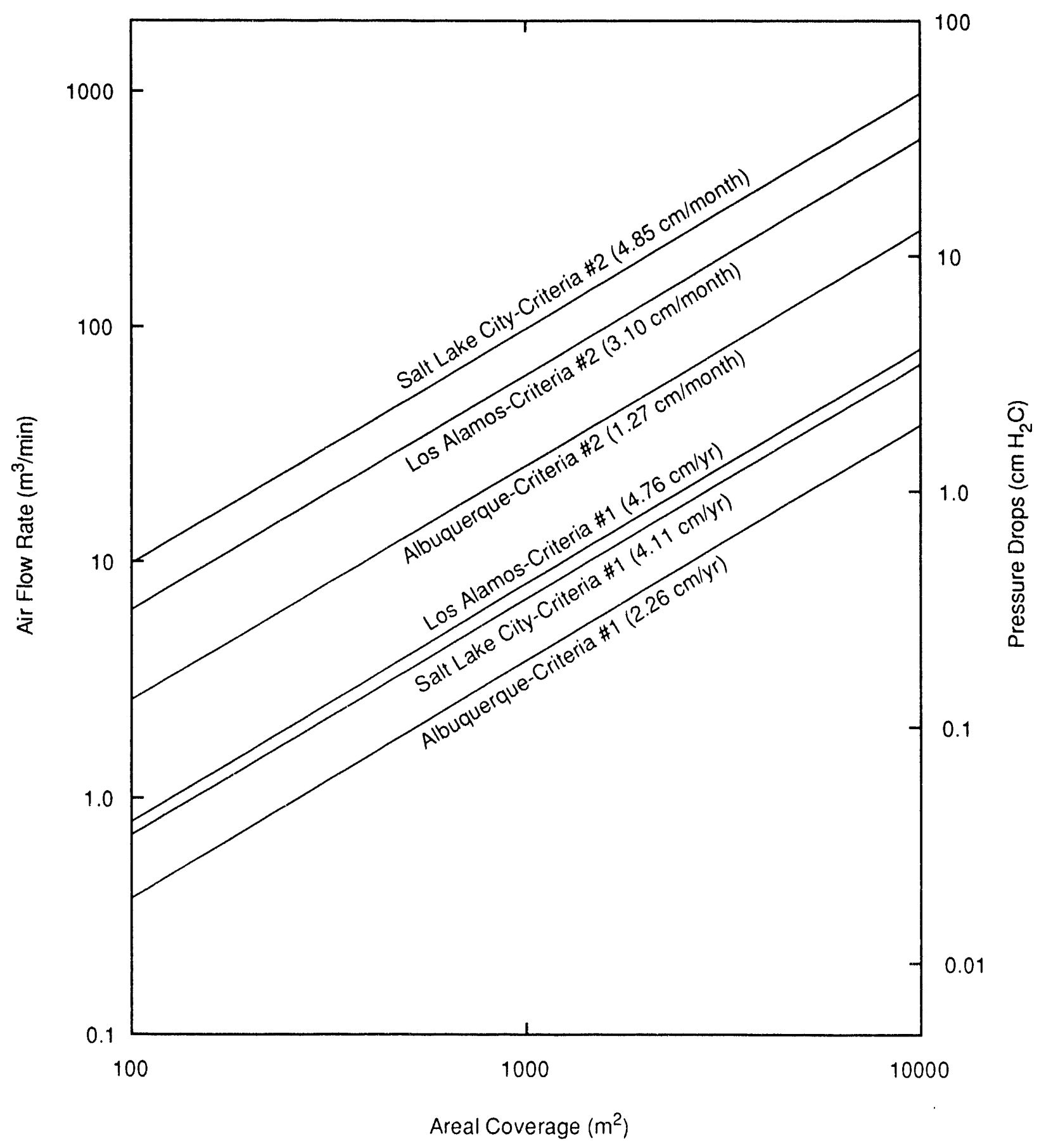

TRI.6621.81.0

Figure 12. Air-flow rates and differential pressures to achieve proposed design criteria for various areal coverages. 
of water vapor in the air stream will be reduced. Because the storage capability of most coarse materials is small, the continued efficient operation of a dry barrier will rely on some water production from the adjacent fine layers into the coarse layer. The more water there is in the fine layer, the more readily the fine layer will release some of this water into the coarse layer. A fine-over-coarse system which is in a state of imminent drainage or failure is the most effective means of supplying water from the fine to the coarse layer. This suggests that dry barriers that utilize low-storage coarse layers should be designed and evaluated with respect to Criterion 2.

\subsection{A DRY BARRIER WITH COARSE LAYER STORAGE}

An ideal coarse layer for a dry barrier would have a large storage capacity. A large volume of water could be stored in the coarse layer and could be gradually removed over time, consistent with the less stringent Criterion 1. Crushed volcanic tuff may possess a combination of properties that may make it an ideal coarse-layer material. Many of the unwelded tuffs in the Los Alamos vicinity possess very high porosity (up to $50 \%$ ). This porosity, termed primary porosity, consists of small, interconnected pores. These tuffs can be readily processed into gravel-sized products that possess a high secondary porosity, the interstitial voids between individual pieces of tuff. The high primary porosity is available for water storage, and the high secondary porosity results in a great air permeability.

The properties of a hypothetical crushed tuff coarse layer are given in Table 4 . The water content of the secondary porosity at field capacity is small because it, as it is for any coarse-grained material, is on the order of $1 \%$. Because of the pore-size distribution of the primary porosity, it will possess a substantial amount of water at typical field capacity suctions (about $70 \%$ saturation). This amount of water corresponds to a water content of $17 \%$. Thus, the total water content in the coarse layer at field capacity is $18 \%$. The permeability assumed for the crushed tuff corresponds to pea-gravel-sized particles.

We can now apply the previous analyses to a system of dimensions (given in Figure 9), which utilizes crushed tuff in the coarse layer. With a pressure drop of $200 \mathrm{~cm}$ and the properties assumed in Table 4, we can remove moisture in the crushed tuff layer at a rate of .12 $\mathrm{cm} /$ day (Figure 11). In only 45 days, we could remove all of the water contained in the crushed tuff. At this water-removal rate, both design criteria can be readily achieved. This analysis suggests that a crushed tuff dry barrier could act as a "sponge" for a cover system because the primary porosity of the tuff permits it to retain $5.4 \mathrm{~cm}$ of water. 
Table 4. Assumed Tuff Properties

\begin{tabular}{|c|c|c|}
\hline $\begin{array}{c}\text { Air } \\
\text { Permeability at } \\
1 / 10 \mathrm{bar} \\
\left(\mathrm{m}^{2}\right)\end{array}$ & $\begin{array}{l}\text { Primary } \\
\text { Porosity } \\
\text { Corrected }\end{array}$ & $\begin{array}{l}\text { Primary Porosity } \\
\text { Water Content } \\
\text { at } 1 / 10 \mathrm{bar} \\
(\% \mathrm{vol} / \mathrm{wt})\end{array}$ \\
\hline $1.6 \times 10^{-8}$ & 0.40 & $1 \%$ \\
\hline & Secondary Porosity & \\
\hline $\begin{array}{l}\text { Secondary } \\
\text { Porosity } \\
\text { Connected }\end{array}$ & $\begin{array}{c}\text { Water Content } \\
\text { at } 1 / 10 \text { bar } \\
(\% \text { vol })\end{array}$ & $\begin{array}{c}\text { Total } \\
(\% \mathrm{vol} / \mathrm{vol})\end{array}$ \\
\hline 0.24 & 0.17 & 0.18 \\
\hline
\end{tabular}


$-$

\section{-}

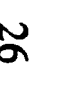

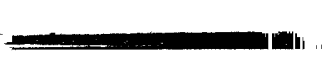

$\exists$

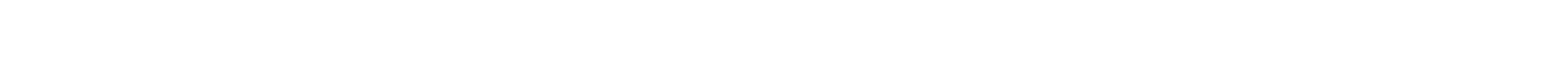

2




\subsection{Application Design and Cost Analysis}

\subsection{SYSTEM REQUIREMENTS}

There are two principal considerations in the design of a dry barrier system for a particular application. First, the geometry of the cover that the system should service must be considered. Larger areas and longer flow paths require greater pressures and larger flow rates. Second, the desired water-removal rate must be specified.

We will consider the basic design unit described in Chapter 4 and illustrated in Figure 9. Two parallel lines are buried in the coarse layer. One line employs positive pressure with ambient air flowing into the system (source). The other line is under a vacuum, with moist air flowing out of the system (sink). Because the pressure and vacuum lines are effectively plumbed in series, each blower's static pressure should combine with the other's to equal the required pressure drop to move the prescribed volume of air between the two lines. Additionally, because of the symmetry of the "modular" unit, only half of the flow from each line source moves toward the line sink shown. The other half of the air will be flowing in the opposite direction, toward a line sink in the adjacent unit. As a consequence, each blower must be sized to provide twice the flow rate and half the pressure drop required to move the air between the lines. A larger cover can be accommodated by simply utilizing the number of dry barrier design units necessary to achieve the desired areal coverage. Designs of dry barrier systems for smaller covers or different dimensions can be developed from the dry barrier design unit because of the approximately linear relationships between the spacing of the lines within the coarse layer and the required pressure drop, and between the volumetric flow rate and the length of the lines.

Designs were developed for six different dimensions to indicate the effect of areal coverage on the design. Dimensions are given in Table 5.

We selected three locations to develop dry barrier designs for a hypothetical landfill cover: Albuquerque, NM; Los Alamos, NM; and Salt Lake City, UT. The applications at Albuquerque and Salt Lake City are for the two-layer or three-layer cover systems, using conventional materials: gravels, sands, and topsoil. For this type of design, the criterion to remove an amount of moisture equal to the precipitation during the "worst" month is the most rigorous (Criterion 2). Because of the proximity of the Los Alamos site to sources of tuffaceous gravels, we will assume the alternative design, incorporating tuff for this site. As a result of the large storage capacity of this material, it is likely that the layer will be able to store the precipitation during the "worst" periods, and the drying of the layer can be accomplished over 
Table 5. Dimensions of Design Unit Cells

\begin{tabular}{|c|c|c|c|}
\hline $\begin{array}{l}\text { Unit Cell } \\
\text { Area }\left(\mathrm{m}^{2}\right)\end{array}$ & $\begin{array}{c}\text { Unit Cell } \\
\text { Length by width (m) }\end{array}$ & Flow path length $(\mathrm{m})$ & pipe length (m) \\
\hline 100 & $10 \times 10$ & 5 & 10 \\
\hline 200 & $14.2 \times 14.2$ & 7.1 & 14.2 \\
\hline 1000 & $31.6 \times 31.6$ & 15.8 & 31.6 \\
\hline 2000 & $44.7 \times 44.7$ & 22.35 & 44.7 \\
\hline 10000 & $100 \times 100$ & 50 & 100 \\
\hline 20000 & $141.4 \times 141.4$ & 70.7 & 141.4 \\
\hline
\end{tabular}

the course of a year. Consequently, we will design this application in light of removing $10 \%$ of the annual precipitation (Criterion 1).

The system requirements in terms of flow rates and pressure drops for the locations and design criteria described above are given in Table 6. To illustrate the effects of the cover geometry on the system requirements, three areal coverages are given. $A 10^{-7} \mathrm{~m}^{2}$ permeability is assumed for the coarse layer. The required air-flow rates and pressure drops in the table are based on the analyses given in Chapter 4. Two important assumptions inherent in these calculations are that the incoming air is assumed to be at $13^{\circ} \mathrm{C}$ and is in equiibrium with the cover materials $\left(13^{\circ} \mathrm{C}\right.$ is the estimated mean soil temperature for these locations), and that the air increases its specific humidity by $50 \%$ as it passes through the cover.

Our design analysis does not include consideration of gas produced by the waste itself. Some wastes will produce gases that are lighter than air, such as methane and radon. These gases will move up through the waste and into the cover. All cover systems must account for the potential for waste-generated gas production. If the gas enters the coarse layer of a dry barrier, it will be carried with the air moving through the layer and be expelled to the atmosphere. Three simple strategies for dealing with such gases are: 1) depending on the type of gas and its concentration, it may be permittable to simply vent the gas to the atmosphere; 2) collect the gas as it exits the coarse layer and treat or dispose of it as appropriate; 3) collect the gas with a collection system between the waste and the dry barrier and deal with it as appropriate. The best solution for a cover system will depend on the site-specific waste characteristics. 


\subsection{EQUIPMENT AND MATERIALS}

A wide range of air-handling equipment was evaluated using the Product Performance Data Program (PC version) provided by American Fan Company. This program employed a

Table 6. Flow Rates and Pressure Drops to Satisfy Design Criteria

\begin{tabular}{|c|c|c|c|c|}
\hline Location & $\begin{array}{c}\text { Design } \\
\text { Criterion } \\
\end{array}$ & $\begin{array}{c}\text { Areal } \\
\text { Coverage } \\
\left(\mathrm{m}^{2}\right) \\
\end{array}$ & $\begin{array}{c}\text { Required } \\
\text { Air } \\
\text { Flow Rate } \\
\left(\mathrm{m}^{3} / \mathrm{min}\right)\end{array}$ & $\begin{array}{c}\text { Required } \\
\text { Pressure } \\
\text { Drop } \\
\text { (cm water) } \\
\end{array}$ \\
\hline Albuquerque & $\begin{array}{l}1.27 \\
\mathrm{~cm} / \text { month, } \\
\text { Criterion } 2\end{array}$ & $\begin{array}{l}100 \\
1000 \\
10,000\end{array}$ & $\begin{array}{r}2.6 \\
25.9 \\
259\end{array}$ & $\begin{array}{c}0.13 \\
1.31 \\
13.0\end{array}$ \\
\hline Los Alamos & $\begin{array}{l}4.76 \mathrm{~cm} / \mathrm{yr} \\
\text { Criterion } 1\end{array}$ & $\begin{array}{l}100 \\
1000 \\
10,000\end{array}$ & $\begin{array}{c}0.8 \\
8.1 \\
81\end{array}$ & $\begin{array}{l}0.04 \\
0.41 \\
4.1\end{array}$ \\
\hline Salt Lake City & $\begin{array}{l}4.85 \\
\mathrm{~cm} / \text { month, } \\
\text { Criterion } 2\end{array}$ & $\begin{array}{l}100 \\
1000 \\
10,000\end{array}$ & $\begin{array}{l}9.9 \\
99 \\
990\end{array}$ & $\begin{array}{r}0.5 \\
4.9 \\
48.8\end{array}$ \\
\hline
\end{tabular}

series of user-entered parameters such as temperature, altitude, flow rate, and static pressure to scan a data base for applicable equipment. The program surveyed the product line from a single manufacturer (American Fan Company, Fairfield, $\mathrm{OH}$ ). However, other sources offer comparable equipment with similar performance options and prices. The models and associated costs cited in this report are for illustration purposes and could vary for different locations, systems, or manufacturers.

Three general types of air blowers were found to be applicable to the locations considered (and for dry barrier applications in general). They are industrial exhausters, backwardly inclined blowers, and pressure blowers. Industrial exhausters offer high flow rates at small to moderate static pressures (for example, $1100 \mathrm{~m}^{3} / \mathrm{min}$ and $53 \mathrm{~cm}$ static pressure at $188 \mathrm{BHP}$ ). They are also well suited to the handling of any particulate (dust) that may become entrained with the airstream. This could be an important consideration for the vacuum side of the dry barrier applications, depending on the degree of coarse layer sorting. Backwardly inclined blowers more efficiently generate high flow rates than do industrial exhausters at small to moderate static pressures (for example, $1000 \mathrm{~m}^{3} / \mathrm{min}$ and $20 \mathrm{~cm}$ static pressure at $75 \mathrm{BHP}$ ). Their main benefit 
is a generally smaller horsepower requirement per given flow rate. These fans are not specifically designed to handle particulates in the air stream, but filters or cyclonic separation could be incorporated into a design to eliminate particulates. Pressure blowers are specifically designed to generate higher static pressures than either industrial exhausters or backwardly inclined blowers; however, they are not able to generate the high flow rates (for example, 70 $\mathrm{m}^{3} / \mathrm{min}$ and $264 \mathrm{~cm}$ static pressure at $65 \mathrm{BHP}$ ).

Installation and maintenance of the blowers do not significantly vary among the three types. All installations will require the appropriate power (either 230,460 , or 575 volts) rated to supply the necessary amperage. For example, a system with two, 100-horsepower, 460 -volt blowers would require a minimum full load current supply of 250 amps (three-phase, AC, induction-type motors). The specification of totally enclosed, fan-cooled (TEFC) motors will allow the equipment to remain exposed to the weather or necessitate only minimal physical structures to house the blowers. Other equipment and facility improvements associated with the blowers will include outlet dampers to control the flow rates and manifolds to distribute the flow to the appropriate location in the system. Pipe required to distribute the flow into the barrier will depend on both the velocity of the air and the static pressure generated by the blower. Higher flow rates will require larger diameter pipe or possibly larger cross-sectional area duct work feeding more than one pipe plumbed in parallel; higher static pressures will generate more heat (roughly a $0.4^{\circ} \mathrm{C}$ increase in temperature is associated with a $2.54 \mathrm{~cm}$ increase in pressure), which may necessitate pipe made of materials other than polyvinyl chloride (PVC)-the least expensive and most readily available material. In all cases, the blowers will need to be moored on concrete or similar pads to alleviate movement caused by vibration. Standard efficiency TEFC motors of the types and sizes incorporated in the following discussion can be expected to run continuously at peak performance for periods of five to seven years. Premium efficiency motors, which are available at a $30 \%$ to $40 \%$ increase in price, could be expected to last three to four times longer. Mutor size, pricing, and power cost information for a range of blowers are given in Appendix B.

No maintenance is expecter for the piping laid within the coarse layer. In all applications, the most cost-effective piping option is $10-\mathrm{cm}$ diameter, perforated, drain-field PVC pipe comparable to what is standard for leach field applications (readily available at approximately $\$ 1.31 / \mathrm{m}$ ). Overburden pressures resulting from approximately $1-\mathrm{m}$ burial present no collapsing problems for standard drain-field pipe as long as the temperature rating of the pipe is not exceeded. 
The dry barrier applications below are deliberately configured to support a manual control system. A simple system would consist of a humidity sensor on the outlet of the blowers and a single flow damper on the inlet and outlet blowers. The most straightforward parameter available to monitor the effect of a dry barrier is the water content of the air as it exits the system. If the relative humidity of the exiting air approaches $100 \%$, then the air is essentially fully saturated while passing through the barrier. We will refer to this condition as $90+\%$ relative humidity to indicate that complete saturation may not be achievable. If the flow rate is increased by opening the dampers and the humidity is still at $90+\%$, then the system's waterremoval rate is being limited by a low flow rate. Continual increases in the flow rate will either reach the maximum flow rating for the system and result in continual water removal at that rate until the coarse layer begins to dry out, or result in shortened residence times of the air in the barrier, leading to failure to reach equilibrium between the incoming air and the resident pore gas, or result in accelerated drying of the coarse layer, with a (desired) significantly reduced water content. As the system begins to reduce the water content of the coarse layer, the relative humidity will drop below $90+\%$. For optimization and monitoring of the barrier, the system should be run with the exiting air at some arbitrary relative humidity less than but near $90+\%$. This will allow the operator of the system to manually reduce the flow rate as the layer dries to minimize the power consumption of the system while still maximizing water removal.

A more sophisticated system is recommended for unattended applications or for fieldscale evaluation and optimization of the DBT. Such a system would consist of pressure, temperature, humidity, and water content sensors coupled with a control/data acquisition system. A series of temperature and humidity sensors would be installed within the system, as well as at the inlet and outlet blowers, to monitor and map the mass transfer of liquid water in the layer to vapor in the air stream. Information from the pressure, temperature, and humidity sensors would be used in feedback loops to adjust the blower flow rates, minimizing power consumption and maximizing water removal.

\subsection{APPLICATION DESIGNS}

Site-specific design options were developed for Albuquerque, Los Alamos, and Salt Lake City. Tables 7, 8, and 9 provide blower specifications to meet the design requirements for the three locations and design criteria. Because more than one blower type can often satisfy the system requirement, two models are given. 
Table 7. Site-Specific Design for Albuquerque

\begin{tabular}{|c|c|c|c|c|c|}
\hline $\begin{array}{c}\text { Areal } \\
\text { Coverage } \\
\left(\mathrm{m}^{2}\right) \\
\end{array}$ & $\begin{array}{c}\text { Blower Air } \\
\text { Flow Rate } \\
\left(\mathrm{m}^{3} / \mathrm{min}\right)\end{array}$ & $\begin{array}{c}\text { Pressure Drop } \\
\text { Across } \\
\text { Flow Path } \\
\text { (cm w.c.) } \\
\end{array}$ & $\begin{array}{c}\text { Blower Static } \\
\text { Pressure } \\
\text { (cm w.c.) } \\
\end{array}$ & $\begin{array}{c}\text { Blowers } \\
\text { Required Inlet } \\
\text { (model, hp) }\end{array}$ & $\begin{array}{c}\begin{array}{c}\text { Outlet } \\
\text { (model, hp) }\end{array} \\
\end{array}$ \\
\hline 100 & 5.18 & .13 & 3.88 & $\begin{array}{c}\text { AF-9-1030 } \\
0.5 \text { bhp }\end{array}$ & $\begin{array}{c}\text { AF-9-1030 } \\
0.5 \text { bhp }\end{array}$ \\
\hline 200 & 10.44 & .26 & 7.75 & $\begin{array}{c}\text { AH-7 } \\
0.5 \text { bhp } \\
\text { OR } \\
\text { AF-10-1060 } \\
0.75 \text { bhp }\end{array}$ & $\begin{array}{c}\text { AH-7 } \\
0.5 \text { bhp }\end{array}$ \\
\hline 1000 & 51.72 & 1.31 & 15.90 & $\begin{array}{c}\text { AH-9 } \\
5.0 \mathrm{bhp} \\
\text { OR } \\
\text { AF-15 1093- } \\
10 \\
7.0 \mathrm{bhp}\end{array}$ & $\begin{array}{c}\text { AH-9 } \\
5.0 \text { bhp }\end{array}$ \\
\hline 2000 & 103.46 & 2.61 & 21.63 & $\begin{array}{l}\text { AH-11 } \\
15 \text { bhp } \\
\text { OR } \\
\text { BCS-135 } \\
15 \text { bhp }\end{array}$ & $\begin{array}{l}\text { AH-11 } \\
15 \text { bhp }\end{array}$ \\
\hline 10000 & 517.88 & 12.99 & 36.98 & $\begin{array}{c}\text { BCS-300 } \\
75 \text { bhpOR } \\
\text { AH-23 } \\
100 \text { bhp }\end{array}$ & $\begin{array}{c}\text { AH-23 } \\
100 \text { bhp }\end{array}$ \\
\hline 20000 & 1035.28 & 25.82 & 48.47 & $\begin{array}{c}\text { BCS-330 } \\
200 \mathrm{bhp} \\
\text { OR } \\
\text { AH-33 } \\
250 \mathrm{bhp}\end{array}$ & $\begin{array}{c}\text { AH-23 } \\
250 \text { bhp }\end{array}$ \\
\hline $\begin{array}{l}\text { Coarse laye } \\
\text { Criteria } 2\end{array}$ & $\begin{array}{l}\text { bility }=10 \\
1.27 \mathrm{~cm} / \mathrm{m}\end{array}$ & f water & & & \\
\hline
\end{tabular}


Table 8. Site-Specific Design for Los Alamos

\begin{tabular}{|c|c|c|c|c|c|}
\hline $\begin{array}{c}\text { Areal } \\
\text { Coverage } \\
\left(\mathrm{m}^{2}\right)\end{array}$ & $\begin{array}{c}\text { Blower Air } \\
\text { Flow Rate } \\
\left(\mathrm{m}^{3} / \mathrm{min}\right) \\
\end{array}$ & $\begin{array}{l}\text { Pressure } \\
\text { Drop Across } \\
\text { Flow Path } \\
\text { (cm w.c) } \\
\end{array}$ & $\begin{array}{c}\text { Blower Static } \\
\text { Pressure } \\
\text { (cm w.c.) } \\
\end{array}$ & $\begin{array}{c}\text { Blowers } \\
\text { Required Inlet } \\
\text { (model, hp) } \\
\end{array}$ & $\begin{array}{c}\text { Outlet } \\
\text { (model, hp) }\end{array}$ \\
\hline 100 & 1.62 & 0.04 & 3.83 & $\begin{array}{c}\mathrm{AF}-10-1015 \\
0.5 \mathrm{bhp}\end{array}$ & $\begin{array}{c}\text { AF-10-1015 } \\
0.5 \mathrm{bhp}\end{array}$ \\
\hline 200 & 3.26 & 0.08 & 7.66 & $\begin{array}{c}\text { AF-10-1015 } \\
0.75 \text { bhp } \\
\text { OR } \\
\text { RB-251-18.5 } \\
0.5 \text { bhp }\end{array}$ & $\begin{array}{c}\text { AF-10-1015 } \\
0.75 \mathrm{bhp} \\
\text { OR } \\
\text { RB-251-18.5 } \\
0.5 \mathrm{bhp}\end{array}$ \\
\hline 1000 & 16.16 & 0.41 & 15.45 & $\begin{array}{c}\text { AF- } 12-1044 \\
1.5 \text { bhp } \\
\text { OR } \\
\text { AH-7 } \\
1.5 \text { bhp }\end{array}$ & $\begin{array}{l}\text { AH-7 } \\
1.5 \text { bhp }\end{array}$ \\
\hline 2000 & 32.34 & 0.82 & 20.73 & $\begin{array}{c}\mathrm{AH}-12-1093 \\
5.0 \mathrm{bhp} \\
\text { OR } \\
\mathrm{AH}-7 \\
5.0 \mathrm{bhp}\end{array}$ & $\begin{array}{c}\text { AH-7 } \\
5.0 \text { bhp }\end{array}$ \\
\hline 10000 & 161.80 & 4.08 & 32.52 & $\begin{array}{c}\text { BCS-135 } \\
30 \text { bhp } \\
\text { OR } \\
\text { AH-13 } \\
30 \text { bhp }\end{array}$ & $\begin{array}{l}\text { AH-13 } \\
30 \text { bhp }\end{array}$ \\
\hline 20000 & 323.54 & 8.14 & 39.63 & $\begin{array}{c}\text { BCS-182 } \\
60 \mathrm{bhp} \\
\text { OR } \\
\text { AH-15 } \\
75 \mathrm{bhp}\end{array}$ & $\begin{array}{l}\text { AH-15 } \\
75 \text { bhp }\end{array}$ \\
\hline
\end{tabular}


Table 9. Site-Specific Design for Salt Lake City

\begin{tabular}{|c|c|c|c|c|c|}
\hline $\begin{array}{c}\text { Areal } \\
\text { Coverage } \\
\left(\mathrm{m}^{2}\right)\end{array}$ & $\begin{array}{c}\text { Blower Air } \\
\text { Flow Rate } \\
\left(\mathrm{m}^{3} / \mathrm{min}\right)\end{array}$ & $\begin{array}{c}\text { Pressure Drop } \\
\text { Across } \\
\text { Flow Path } \\
\text { (cm w.c.) } \\
\end{array}$ & $\begin{array}{c}\text { Blower Static } \\
\text { Pressure } \\
\text { (cm w.c.) } \\
\end{array}$ & $\begin{array}{c}\text { Blowers } \\
\text { Required Inlet } \\
\text { (model, hp) }\end{array}$ & $\begin{array}{c}\begin{array}{c}\text { Outlet } \\
\text { (model, hp) }\end{array} \\
\end{array}$ \\
\hline 100 & 19.78 & 0.50 & 4.06 & $\begin{array}{c}\text { AF- }-9-1030 \\
2.0 \mathrm{bhp} \\
\text { OR } \\
\text { AH-9 } \\
0.5 \mathrm{bhp}\end{array}$ & $\begin{array}{c}\text { AH-9 } \\
0.5 \text { bhp }\end{array}$ \\
\hline 200 & 39.88 & 1.01 & 8.13 & $\begin{array}{c}\text { AF-15-1121-10 } \\
2.0 \mathrm{bhp} \\
\text { OR } \\
\text { AH-9 } \\
2.0 \mathrm{bhp}\end{array}$ & $\begin{array}{c}\mathrm{AH}-9 \\
2.0 \mathrm{bhp}\end{array}$ \\
\hline 1000 & 197.54 & 4.98 & 17.73 & $\begin{array}{c}\text { BCS-165 } \\
20.0 \text { bhp } \\
\text { OR } \\
\text { AH-15 } \\
20.0 \text { bhp }\end{array}$ & $\begin{array}{c}\mathrm{AH}-15 \\
20.0 \mathrm{bhp}\end{array}$ \\
\hline 2000 & 395.26 & 9.93 & 25.29 & $\begin{array}{c}\text { BCS-200 } \\
50 \text { bhp } \\
\text { OR } \\
\text { AH-21 } \\
50 \text { bhp }\end{array}$ & $\begin{array}{l}\text { AH-21 } \\
50 \text { bhp }\end{array}$ \\
\hline 10000 & 1978.20 & 48.80 & 54.88 & $\begin{array}{c}\text { BCS-542 } \\
400 \text { bhp } \\
\text { OR } \\
2 \text { ea.) } \\
\text { AH-29 } \\
250 \text { bhp }\end{array}$ & $\begin{array}{c}\text { AH-33 } \\
600 \text { bhp } \\
\text { OR } \\
2 \text { ea.) } \\
\text { AH-29 } \\
250 \text { bhp }\end{array}$ \\
\hline 20000 & 3955.20 & 95.47 & 83.30 & $\begin{array}{c}\text { BCS-660 } \\
1100 \text { bhp } \\
\text { OR } \\
4 \text { ea.) } \\
\text { BCS-330 } \\
275 \text { bhp }\end{array}$ & $\begin{array}{c}\text { BCS- } 660 \\
1100 \text { bhp } \\
\text { OR } \\
4 \text { ea.) } \\
\text { BCS-330 } \\
275 \text { bhp }\end{array}$ \\
\hline $\begin{array}{l}\text { Coarse } 1 \\
\text { Criteria }\end{array}$ & $\begin{array}{l}\text { meability } \\
\text { ove } 4.85\end{array}$ & $\begin{array}{l}\mathrm{m}^{2} \\
\text { th of water }\end{array}$ & & & \\
\hline
\end{tabular}


There are two important aspects of performance requirements given in Tables 7, 8, and 9. First, the blower flow rate given is twice the flow rate required between the line source and line sink. This doubling is to account for flow near the atmospheric boundaries of the design unit or where several units are connected. A second important feature is that the static pressure of the blower/vacuum is much greater than that required to induce the desired air flow through the coarse layer. Static pressures required by the system are a function of the coarse-layer permeability and the frictional losses associated with the fittings and plumbing of the system. Figure 13 shows the additional estimated pressure losses incurred with increases in flow rate and system sizes. Exact pressure drops can be determined by rigorous calculation of losses associated with actual fittings and their position in a dry barrier design. Due to the variability of fittings available and the myriad possible configurations to minimize piping and equipment, estimates are used in the selection and costing of the following site-specific designs. For cases of low flow rates and small areal coverages, the estimates are conservative. For systems with higher flow rates and larger areal coverages, pressure losses can be reduced with larger duct work or plumbing.

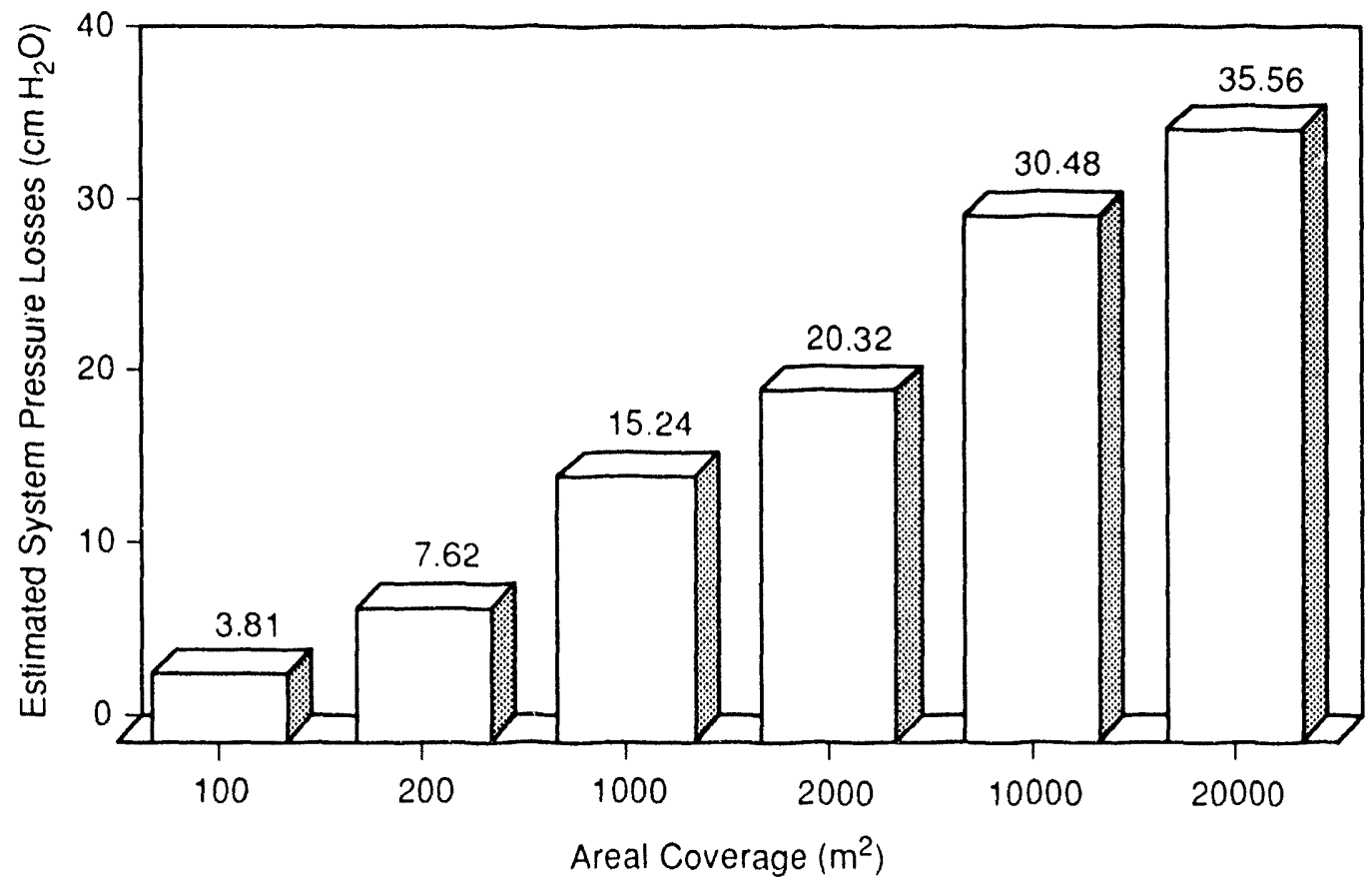

Figure 13. Estimated pressure losses as a function of areal coverage. 


\subsection{COST ANALYSIS}

\subsubsection{CAPITAL COSTS}

The installation of a dry barrier system will involve costs for blowers, pipe, humidity sensors, and gravel. These costs (without a blower) will be a constant for a particular size regardless of specific location. Because it is assumed that a coarse gravel will be included in the cover with or without a dry barrier, this cost is considered separate. Estimates of these costs are given in Table 10.

Piping is estimated at $\$ 1.31 /$ meter for 10 -cm diameter, perforated PVC. Duct work is estimated at $\$ 15.75 /$ meter for a constant 10 -meter length figured to connect the blowers to any buried pipe at all sites. Gravel is estimated at $\$ 16.48 /$ meter $^{3}$. An outlet humidity sensor is estimated at $\$ 500$.

Table 10. Estimated Equipment Costs

\begin{tabular}{|c|c|c|c|c|c|}
\hline Area $\left(m^{2}\right)$ & $\begin{array}{l}\text { Humidity } \\
\text { Sensor } \\
\text { and Duct } \\
\text { work }\end{array}$ & $\begin{array}{l}\text { Piping } \\
\text { Costs }\end{array}$ & $\begin{array}{l}\text { Total Costs } \\
\text { excluding } \\
\text { Blower and } \\
\text { Gravel }\end{array}$ & $\begin{array}{l}\text { Gravel } \\
\text { Costs }\end{array}$ & $\begin{array}{c}\text { Total Cost } \\
\text { excluding } \\
\text { Blower }\end{array}$ \\
\hline 100 & $\$ 657.50$ & $\$ 26.20$ & $\$ 683.70$ & $\$ 495$ & $\$ 1,180$ \\
\hline 200 & $\$ 657.50$ & $\$ 39.30$ & $\$ 696.80$ & $\$ 988$ & $\$ 1,685$ \\
\hline 1000 & $\$ 657.50$ & $\$ 83.25$ & $\$ 740.75$ & $\$ 4,944$ & $\$ 5,685$ \\
\hline 2000 & $\$ 657.50$ & $\$ 117.90$ & $\$ 775.40$ & $\$ 9,888$ & $\$ 10,664$ \\
\hline 10000 & $\$ 657.50$ & $\$ 262.00$ & $\$ 919.50$ & $\$ 49,440$ & $\$ 50,360$ \\
\hline 20000 & $\$ 657.50$ & $\$ 372.00$ & $\$ 1,029.50$ & $\$ 98,880$ & $\$ 99,909$ \\
\hline
\end{tabular}

The total system capital costs are determined by combining the costs given in Table 10 with the costs for the blowers specified in Tables 7, 8, and 9. (Blower costs are given in Appendix B). In Figures 14, 15, and 16, these costs are given on a total cost basis as well as a cost-per-meter basis. These costs do not include gravel. 

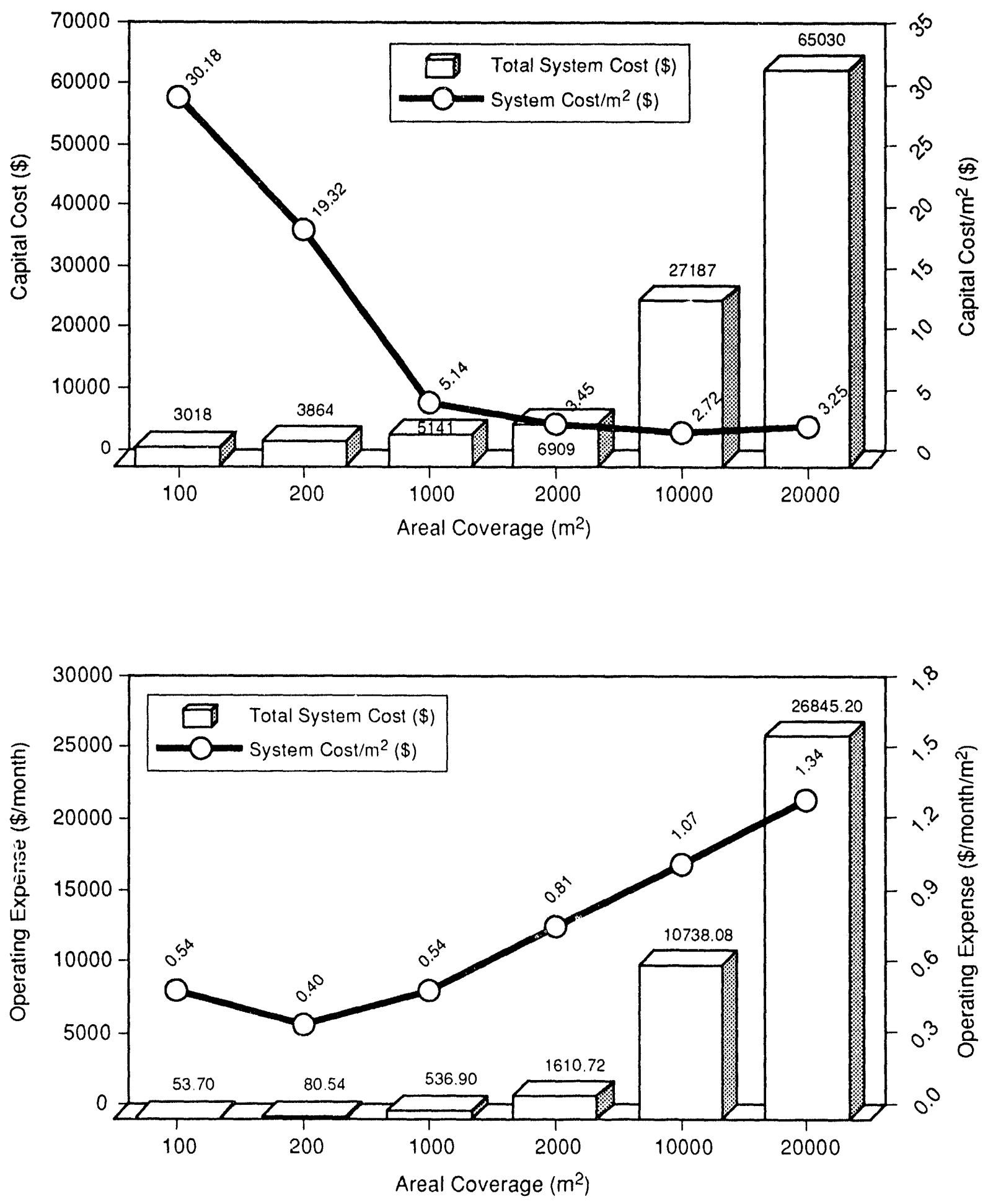

TRI.6621.58.0

Figure 14. Capital and operating costs for the Albuquerque site. 

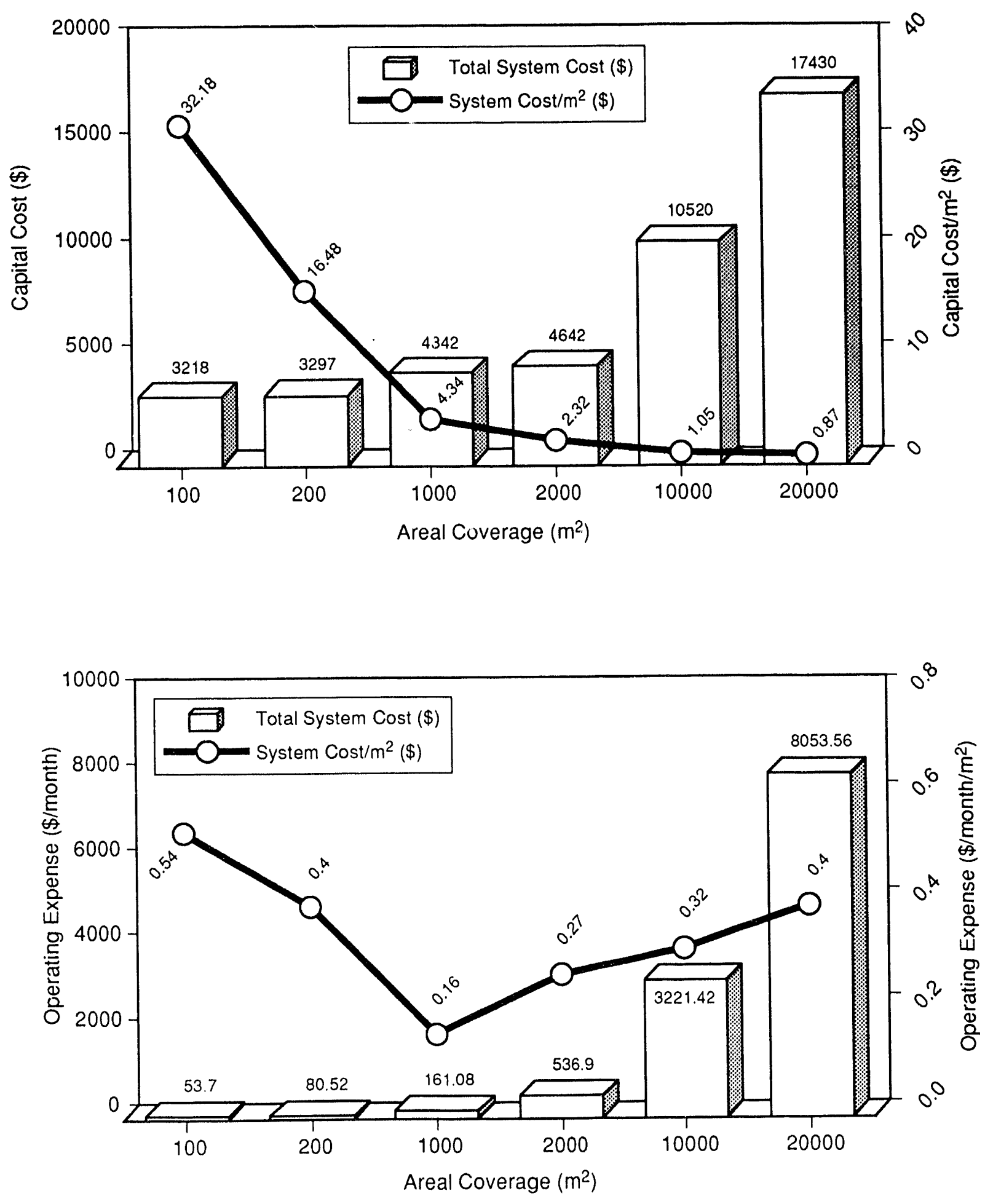

Figure 15. Capital and operating costs for the Los Alamos site. 

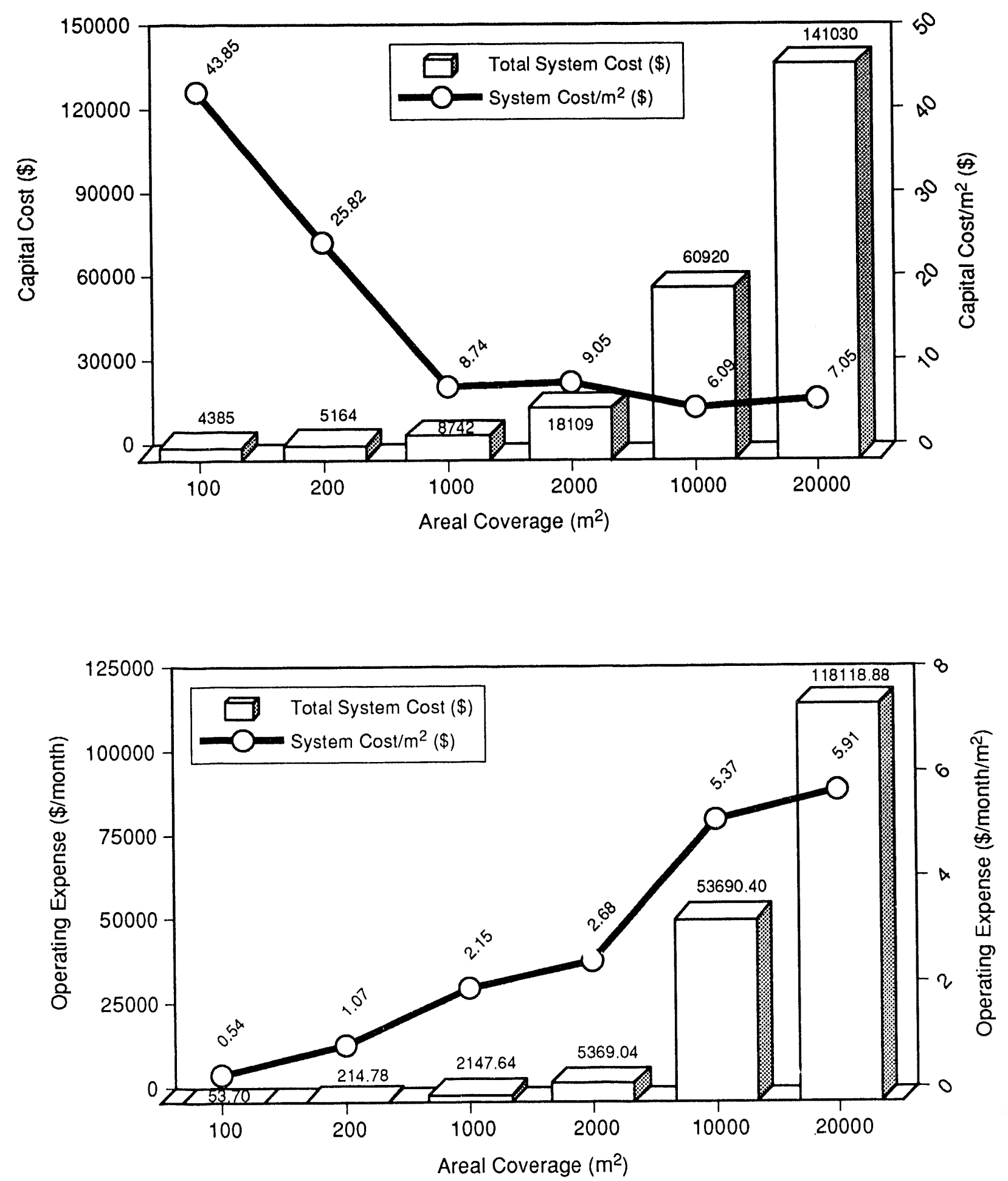

Figure 16. Capital and operating costs for the Salt Lake City site. 


\subsubsection{OPERATING COSTS}

The principal operating costs are those associated with the electricity to run the blowers. It is assumed that a sufficient power source is nearby and available. To calculate the operating costs, the power consumption in watts of a design is determined by converting the motor horsepower requirements into kilowatts for each selected blower (information in Appendix B). A power cost of $\$ 0.10$ kilowatt-hour is then assumed. In Figures 14,15 , and 16 , the total operating expense and the operating expense per meter are given for the three sites as a function of areal coverage.

\subsection{DISCUSSION}

Comparison of the site-specific designs reveals the importance of the selected design criteria. The Los Alamos designs were developed with the first criterion, that is, the removal of $10 \%$ of the annual precipitation. These designs had lower costs than those for Albuquerque or Salt Lake City, which were developed with the second criterion-the removal of the precipitation during a month with no evapotranspiration. The difference between the Los Alamos designs and the others is that they employed gravel-sized tuff, which has a large primary porosity. The use of a coarse layer with primary porosity permits less stringent design requirements and results in power costs. Other materials with high primary porosity, such as zeolites, could be considered for other applications.

The analyses of the capital costs reveal the economies of scale for all sites, that is, the greater the areal coverage the lower the costs on a square meter basis. In contrast, the operating expenses increase on a square meter basis for the Albuquerque and Salt Lake City designs. The Los Alamos designs reveal that $1000 \mathrm{~m}^{2}$ is an optimal size with respect to minimizing operating expenses.

The costs for installing an active dry barrier are comparable to costs for other cover system components. Daniel and Koerner (1992) estimated the cost for a compacted soil layer, a geomembrane, and a geosynthetic clay liner. They derived an approximate cost of $\$ 7.50 / \mathrm{m}^{2}$ for each of these components. Active dry systems of about $1000 \mathrm{~m}^{2}$ have a capital cost on this order (Figures 14, 15, and 16). Of course, the ongoing operating expense (electricity) represents a substantial additional cost. The simple cost analysis does not consider that a dry barrier will reduce the volume of water that moves through the waste and thus reduces the costs associated with the handling, analysis, and disposal of leachate. 
We perceive the biggest obstacle to the use of active dry barriers is the unwillingness of a site owner to commit to the cost of operating a system for the lifetime of the cover. The general perception is that a covered landfill should be closed and inactive. However, the regulations for closure of a hazardous waste landfill mandate maintenance of the cover system for at least 30 years. The monitoring and maintenance of a dry barrier system could be included in the cover maintenance activity. A passive dry barrier system would likely overcome these objections and be much less costly. 


\subsection{Conclusions}

An active dry barrier system can be designed, installed, and operated as part of a landfill cover system. Most landfill cover designs already include a coarse, air-permeable layer that could be used to channel the air flow. Depending principally on the air-flow rate, it is possible for a dry barrier to remove enough water to substantially reduce the likelihood of water percolating through the cover system.

The principal mechanism of water removal is the evaporation of water and advection of water vapor out of the coarse layer. The greater the permeability of coarse layer, the easier it is to move air through the layer. The high permeability, however, is typically accompanied by low water-storage capability. If a material with a relatively large storage capacity is used as the coarsi layer, such as processed tuff, then the efficiency of the dry barrier can be increased.

There are no engineering obstacles to incorporating a dry barrier into a landfill cover. The equipment to establish a dry barrier layer is commercially available blowers and piping. Inclusion of a dry barrier costs about the same as other cover components (e.g., a geomembrane), but it does result in a significant ongoing operating cost for electricity.

The evaluation of DBT will next focus on passive dry barrier systems. We will investigate the potential of passive systems to be low-maintenance, long-lived, and operational components in a cover system. 
(2:- :

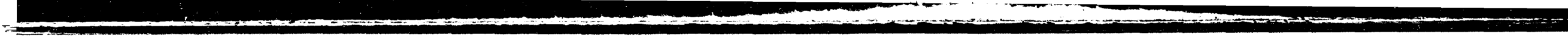




\subsection{References}

D.E. Daniel and R.M. Koerner, 1992, Final Cover Systems in Geotechnical Aspects of Waste Disposal, D.E. Daniel, Editor, Chapman and Hall, London.

Environmental Protection Agency, 1989, Final Covers on Hazardous Waste Landfills and Surface Impoundments, Technical Guidance Document, EPA/530-SW-89-047, Office of Solid Waste and Emergency Response, U.S. Environmental Protection Agency, Washington, D.C.

Environmental Protection Agency, 1991, Design and Construction of RCRA/CERCLA Final Covers, Seminar Publication, EPA/625/4-91/025, U.S. Environmental Protection Agency, Washington, D.D.

T.E. Hakonson, 1986, Evaluation of Geologic Materials to Limit Biological Intrusion into LowLevel Radioactive Waste Disposal Sites, LA-10286-MS, Los Alamos National Laboratory, Los Alamos, NM.

T.E. Hakonson, K.L. Manies, R.W. Warren, K.V. Bostick, G. Trujillo, J.S. Kent, and L.J. Lane, 1992, Migration Barrier Covers for Radioactive and Mixed Waste Landfills, Proceedings of ER Technology Transfer, USAF Center for Environmental Excellence, Jan. 26-28.

R.J. Montgomery, and L.J. Parson, 1989, The Omega Hills Final Cover Test Plot Study: Three-Year Data Summary, Presented at the 1989 Annual Meeting of the National Solid Waste Management Association, Washington, D.C.

J.W. Nyhan, T.E. Hakonson and B.J. Drennon, 1990, "A Water Balance Study of Two Landfill Cover Designs for Semiarid Regions," Journal of Environmental Quality, Vol. 19, No. 2, pp. 281-288.

I.S. Oweis, 1989, "Sanitary Landfill Clay Caps: Do They Inhibit Leachate Generation?" Journal of Resource Management and Technology, Vol. 17, No. 3, October. 
G. Paige, T.E. Hakonson, D.S. Yakowitz, L.J. Lane and J.J. Stone, 1993, A Prototype Decision Support System for the Evaluation of Shallow Land Disposal Trench Cap Designs, DOE ER 93 Environmental Remediation Conference, October 24-28.

K. Pruess, 1991, TOUGH2-A General Purpose Numerical Simulator for Multiphase Fluid and Heat Flow, LBL-29400, Lawrence Berkeley Laboratory, Berkeley, CA.

J.L. Sherard, L.P. Dunnigan, and J.R. Talbot, 1984, "Basic Properties of Sand and Gravel Filters," Journal of Geotechnical Engineering, Vol. 110, No. 6, pp. 684-700.

G.W. Suter II, R.J. Luxmoore, and E.D. Smith, 1993, "Compacted Soil Barriers at Abandoned Landfill Sites are Likely to Fail in the Long Term," Journal of Environmental Quality, Vol. 22, No. 2, pp. 217-226.

O.L. Weeks, R.S. Mansell, and S.W. McCallister, 1992, "Evaluation of Soil Top-Cover Systems to Minimize Infiltration into a Sanitary Landfill: A Case Study," Environmental Geology and Water Science, Vol. 20, No. 2, pp. 139-151.

N.R. Wing and G.W. Gee, Editors, 1990, Hanford Site Protective Barrier Development Program: Fiscal Year 1989 Highlights, WHC-EP-0318, Westinghouse Hanford Co., Richland, WA. 
Appendix A:

Assumed Material Properties

A-1 
Appendix A

Assumed Material Properties

\begin{tabular}{|c|c|c|c|c|}
\hline Material & $\begin{array}{l}\text { Permeability } \\
\left(\mathrm{m}^{2}\right)\end{array}$ & $\begin{array}{c}\text { Saturated } \\
\text { Hydraulic } \\
\text { Conductivity } \\
(\mathrm{cm} / \mathrm{sec})\end{array}$ & Porosity & $\begin{array}{c}\text { Field } \\
\text { Capacity* }^{*} \\
\text { (\% Vol/vol) }\end{array}$ \\
\hline Sandia Topsoil & $8.86 \times 10^{-14}$ & $8.63 \times 10^{-5}$ & .39 & .28 \\
\hline 100" SAND & $3.34 \times 10^{-12}$ & $3.25 \times 10^{-3}$ & .42 & .12 \\
\hline 20-40 SAND & $2.36 \times 10^{-11}$ & $2.3 \times 10^{-2}$ & .39 & .02 \\
\hline 10-20 SAND & $1.33 \times 10^{-10}$ & $1.3 \times 10^{-1}$ & .38 & .01 \\
\hline $\begin{array}{l}\text { Well Graded } \\
\text { Gravel }\end{array}$ & $3.59 \times 10^{-10}$ & $3.5 \times 10^{-1}$ & .42 & .01 \\
\hline $\begin{array}{l}\text { Med. Graded } \\
\text { Gravel** }\end{array}$ & $1 \times 10^{-9}$ & $9.8 \times 10^{-1}$ & $\approx .35$ & $<.01$ \\
\hline Clean Gravel** & $1 \times 10^{-8}$ & $9.8 \times 10$ & $\approx .35$ & $<.01$ \\
\hline Cobbles** & $>1 \times 10^{-7}$ & $9.8 \times 10^{1}$ & $\approx .35$ & $<.01$ \\
\hline
\end{tabular}

\section{Reference}

R.A. Freeze and J.A. Cherry, 1979, Groundwater, Prentice-Hall, Englewood Cliffs, NJ. 


$$
\text { A-4 }
$$


Appendix B:

Blower Specifications and Costs

B-1 
B-2 


\section{APPENDIX B \\ Blower Specifications and Costs}

Blower pricing is listed in Table B-1. The model numbers denote the type of equipment employed; AH signifies an industrial exhauster; BCS denotes a backward-inclined blower; RB or AF indicates a pressure blower. The Blower Purchase Cost column reflects the blower and outlet damper price f.o.b. the manufacturer in Dayton, OH. The Power Cost coiumns reflect a conversion of horsepower-hours to kilowatt-hours and the application of a set fee per kilowatthour. The costs associated with running the blower at full load and at $25 \%$ of full load are given. Motor loads will vary with outlet damper settings. Full open dampers will run the motors at full load and one-fourth open dampers will run the motors at approximately one-fourth load. 
Table B-1. Prices of Blowers

\begin{tabular}{|c|c|c|c|c|}
\hline $\begin{array}{l}\text { Blower } \\
\text { Model \# }\end{array}$ & $\begin{array}{c}\text { Motor Size } \\
\text { (horsepower) }\end{array}$ & $\begin{array}{l}\text { Approximate } \\
\text { Purchase Cost }\end{array}$ & $\begin{array}{c}\text { Power Cost (at } \\
\$ 0.10 / \mathrm{KWH} 30 \\
\text { days at full } \\
\text { load) }\end{array}$ & $\begin{array}{c}\text { Power Cost (at } \\
\$ 0.10 / \mathrm{KWH} 30 \\
\text { days at } 25 \% \text { full } \\
\text { load) }\end{array}$ \\
\hline AH-9 & 15 & 3125 & $\$ 805.36$ & $\$ 201.34$ \\
\hline $\mathrm{AH}-11$ & 15 & 3467 & $\$ 805.36$ & $\$ 201.34$ \\
\hline AH-13 & 15 & 3967 & $\$ 805.36$ & $\$ 201.34$ \\
\hline AH-13 & 30 & 4800 & $\$ 1610.71$ & $\$ 402.68$ \\
\hline AH-15 & 25 & 4934 & $\$ 1342.26$ & $\$ 335.57$ \\
\hline AH-19 & 25 & 6200 & $\$ 1342.26$ & $\$ 335.57$ \\
\hline AH-19 & 35 & 7800 & $\$ 1879.16$ & $\$ 469.79$ \\
\hline $\mathrm{AH}-21$ & 200 & 20,000 & $\$ 107378.08$ & $\$ 2684.52$ \\
\hline AH-23 & 100 & 14,667 & $\$ 5369.04$ & $\$ 1342.26$ \\
\hline AH-29 & 125 & 20,000 & $\$ 6711.30$ & $\$ 1677.83$ \\
\hline AH-33 & 125 & 22,000 & $\$ 6711.30$ & $\$ 1677.83$ \\
\hline AH-33 & 150 & 25,000 & $\$ 8323.56$ & $\$ 2013.39$ \\
\hline AH-33 & 250 & 32,000 & $\$ 13422.60$ & $\$ 3355.65$ \\
\hline BC- 135 & 15 & 2667 & $\$ 803.38$ & $\$ 201.34$ \\
\hline BC- 182 & 25 & 3467 & $\$ 1342.26$ & $\$ 335.57$ \\
\hline BC- -300 & 75 & 11,600 & $\$ 4026.78$ & $\$ 1006.70$ \\
\hline R-305-19.5 & 30 & 6934 & $\$ 1610.71$ & $\$ 402.68$ \\
\hline R-355-19.5 & 30 & 7534 & $\$ 1610.71$ & $\$ 402.68$ \\
\hline$R-355-20$ & 40 & 8200 & $\$ 2147.62$ & $\$ 536.90$ \\
\hline$R-455-28$ & 100 & 14,667 & $\$ 5369.04$ & $\$ 1342.26$ \\
\hline
\end{tabular}




\section{DISTRIBUTION}

\section{Federal Agencies}

US Department of Energy

Albuquerque Operations Office

Attn: National Atomic Museum Library

PO Box 5400

Albuquerque, NM 87185-5400

US Department of Energy

Albuquerque Operations Office

ETN

Attn: Pam Saxman (2)

Pennsylvania/H Street

Albuquerque, NM 87116

US Department of Energy

Albuquerque Operations Office

ERPO

Attn: Julianne Levings

Pennsylvania/H Street

Albuquerque, NM 87116

US Department of Energy

Research \& Waste Management Division

Attn: Director

PO Box E

Oak Ridge, TN 37831

US Department of Energy

Office of Environmental Restoration and Waste Management

Attn: J. Lytle, EM-30,

Trevion II

Washington, DC 20585-0002

US Department of Energy (3)

Office of Environmental Restoration and Waste Management

Attn: M. Frei, EM-34,

Trevion II

Washington, DC 20585-0002

US Department of Energy

Office of Environmental Restoration

and Waste Management

Attn: S. Schneider, EM-342,

Trevion II

Washington, DC 20585-0002
US Department of Energy (3)

Office of Technology Development

Attn: S. Chamberlain, EM-551, Trevion II

19901 Germantown Rd

Germantown, MD 20874-1290

\section{State Agencies}

NM Bureau of Mines and Mineral Resources

Socorro, NM 87801

NM Energy, Minerals, and Natural

Resources Department

Attn: Library

2040 S. Pacheco

Santa Fe, NM 87505

NM Environment Department (3)

Secretary of the Environment

Attn: J. Espinosa

1190 St. Francis Drive

Santa Fe, NM 87503-0968

\section{Laboratories/Corporations}

D.B. Stephens \& Assoc., Inc. (4)

Attn: Mark Ankeny

6020 Academy NE, Suite 100

Albuquerque, NM 87109

Los Alamos National Laboratory

Attn: B. Erdal, INC-12

PO Box 1663

Los Alamos, NM 87544

Tech Reps Inc. (3)

Attn: T. Peterson

5000 Marble NE, Suite 222

Albuquerque, NM 87110

\section{Libraries}

Thomas Brannigan Library

Attn: D. Dresp

106 W. Hadley St.

Las Cruces, NM 88001 
Government Publications Department

Zimmerman Library

University of New Mexico

Albuquerque, NM 87131

New Mexico Junior College

Pannell Library

Attn: R. Hill

Lovington Highway

Hobbs, NM 88240

New Mexico State Library

Attn: N. McCallan

325 Don Gaspar

Santa Fe, NM 87503

New Mexico Tech

Martin Speere Memorial Library

Campus Street

Socorro, NM 87810

\section{Internal}

$\begin{array}{lll}\underline{\text { MS }} & \text { Org } & \\ 0715 & 6603 & \text { R. Luna } \\ 0719 & 6621 & \text { J. E. Nelson } \\ 0619 & 6621 & \text { Staff (15) } \\ 0619 & 6621 & \text { J. C. Stormont (10) } \\ 0724 & 6000 & \text { D. L. Hartley } \\ 0726 & 6600 & \text { J. Woodard } \\ 0756 & 6607 & \text { G. Allen } \\ 0899 & 7141 & \text { Technical Library (5) } \\ 0619 & 7151 & \text { Technical Publications } \\ 0100 & 7613-2 & \text { Document Processing for } \\ & & \text { DOE/OSTI (10) } \\ 9018 & 8523-2 & \text { Central Technical Files }\end{array}$



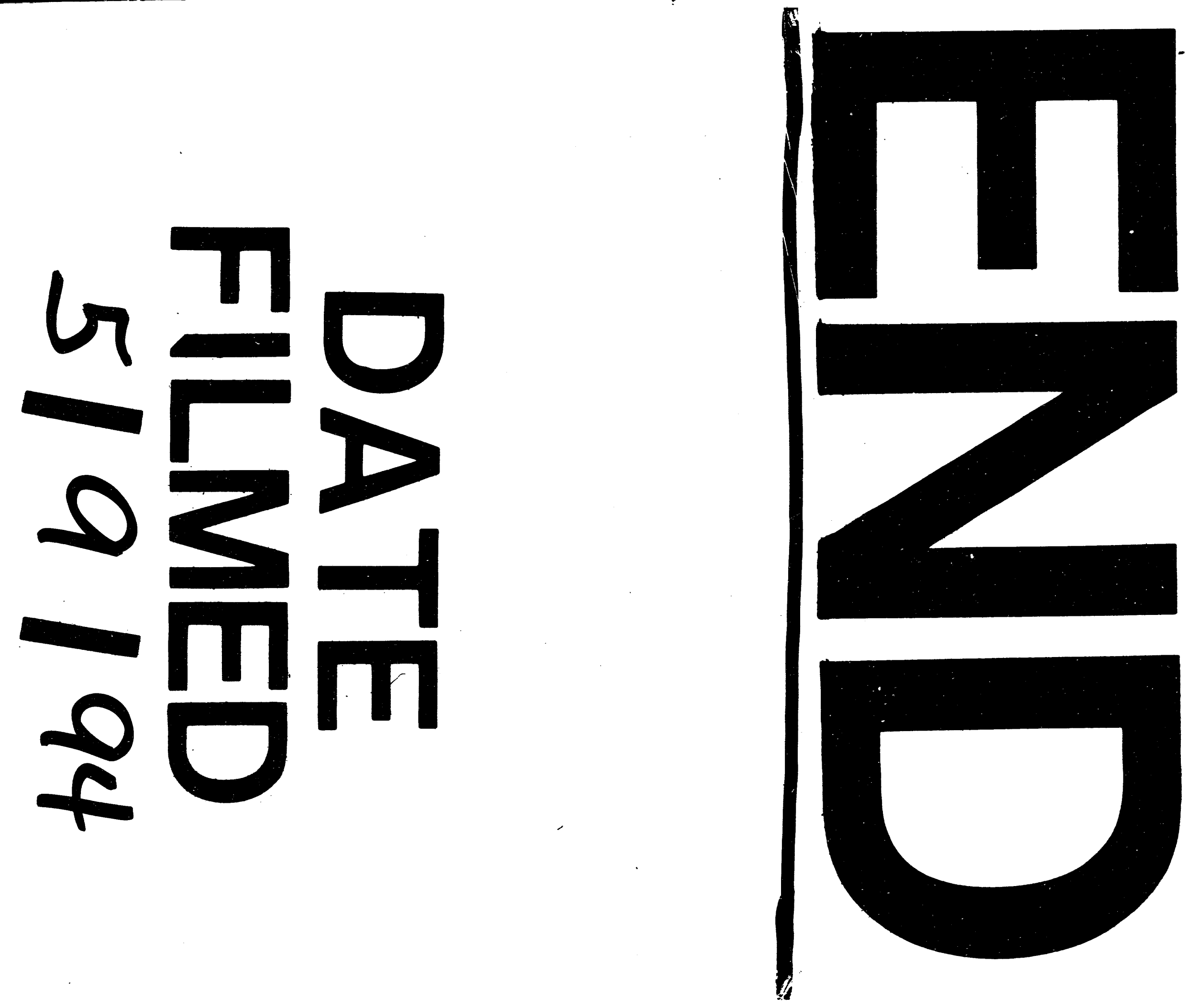

1 
